感情プライミングが ERP に及ぼす影響

一顔表情の無意識 - 意識処理と文化効果の視点から-

○近藤晴香（名古屋大学大学院 環境学研究科）

沖田庸嵩 (愛知淑徳大学 コミュニケーション学部)

\section{問 翅}

脳は感覚器官から入ってくる膨大な量の情報を たえず受け止め, その処理結果は無意識的・意識的 なレベルで私たちの日常行動の基盤となっている。 Liddell et al. (2004) は顔表情の認知について ERP で分析し, 閾下条件では N2 と P3a が惹起し, 闇上 条件ではさらに N4 と P3bが惹起したことから無意 識処理と意識処理の分離を示唆した。さらに，差し 迫った劦威を示寸恐怖表情はこれら4つの ERP 成 分で振幅の増大と潜時の減少をもたらすと報告した。 そこで，本研究では Liddell et al（2004）の結果 の追試と，所属文化の顔を選択的に処理するという 文化効果 (Chiao et al., 2008）の視点から, 顔表情 が ERPに及ぼす影響について検討することとした。 Liddell et al（2004）の結果から，恐怖表情はいず れの $\mathrm{ERP}$ 成分 (N2，P3a， N4，P3b）で潜時の減 少と振幅の増大をもたらすと予測できる。文化効果 は表情に関わらず所属文化である日本人顔に対し，

これら 4 つの ERP 成分で潜時の減少と振幅の増大 が予測される。

\section{方 法}

実験参加者 $20-36$ 歳の大学生のうち男性 14 名, 女性 14 名, 計 28 名であった。全ての実験参加者は 右手利きであった。

刺激 Matsumoto \& Ekman（1989)の顔感情シ リーズより，日本人顔と西欧人顔それぞれで 4 種類 の恐怖顔と 4 種類の幸福顔であり，それぞれに対応 する 16 種類の真顔であった。

要因計画 2 (文化差: 日本人/西欧人) $\times 2$ (情動: 恐怖顔/幸福顔） $\times 2$ (刺激呈示時間 : 閾下/閾上) の いずれの要因も被験者内要因とした。

手続き 刺激呈示の説明後に連続して呈示される ターゲット顔への感情判断であった。各試行では, まず画面に凝視点 $1 \mathrm{~s}$ 間呈示され，次にプライムと なる情動顔 (恐怖顔/幸福顔) が $15 \mathrm{~ms}$ もしくは 170 $\mathrm{ms}$ 間呈示された。最後にターゲットである真顔が $800 \mathrm{~ms}$ 間呈示され，このときに感情判断を行わせ
た。1ブロック 42 試行を 10 ブロック行った。実験 課題後の意識チェックで闇下条件と同様の刺激に感 情判断を行わせ, プライムに対する知覚の程度を調 べた。

\section{結果と考察}

閾条件別に潜時と振幅について 2 (文化: 日本人) 西欧人） $\times 2$ (情動：恐怖/幸福） $\times 3$ （部位： $\mathrm{Fz} / \mathrm{Cz} / \mathrm{Pz})$ の分散分析を行ったところ, 䦨下条件で は N2 成分で文化効果は得られたが，表情効果は観 察されなかった。P3a では表情効果も文化効果も観 察されなかった。意識チェックの正答率がチャンス レベルを超えて有意であったことからも感情の無意 識的過程を実験によって証明することへの問題点を 多く残すかたちとなった。䦨上条件では N4 成分で 文化効果が得られ，P3b 成分で表情効果が観察され た (図 1，2参照)。まず, 自動処理過程で文化関連 の情報が処理され，それが N4 に表出する。ついで， 制御処理過程で表情関連の情報が処理され P3b に 反映される。こうして，N4 と P3bにそれぞれ文化 効果と表情効果が直列的に表出したと解釈できる。 しかしこの可能性について本研究で検証することは 難しく, 今後に残された課題である。

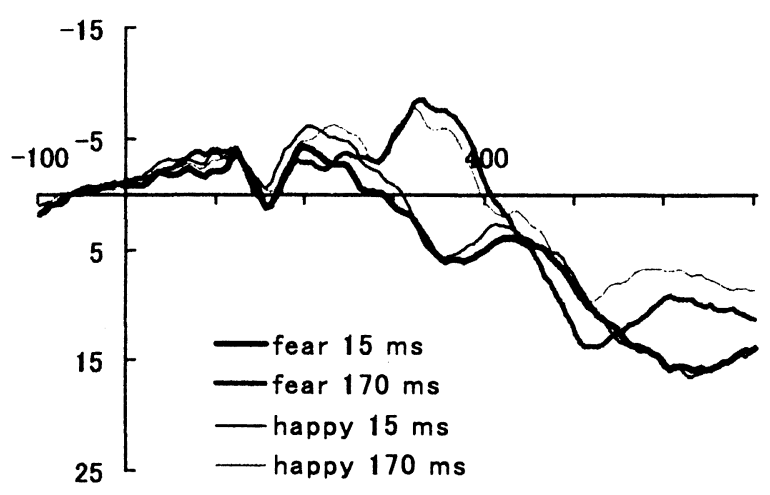

図 $1 \mathrm{Pz}$ における日本人顔呈示の GA 波形

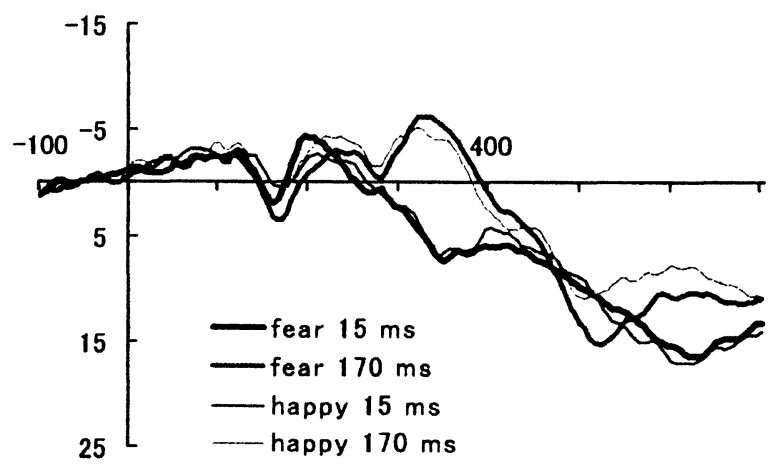

図2 $\mathrm{Pz}$ における西欧人顔呈示の GA 波形 


\section{感情誘発スライドに対する意図的表情表出の潜時}

○小時洋 (科学警察研究所情報科学第一研究室)

廣田昭久 (科学警察研究所情報科学第一研究室)

松田いづみ (科学警察研究所情報科学第一研究室)

表情は，感情・情動の表出形態の一つであり，表 出・解読両面から数多くの研究が行われている。そ の中で，筋電図を用いた表情筋活動 (facial elect romyography, fEMG) は, 表情表出研究のッールのつとして,また感情や態度の指標の一つとして研究 されてきた。それらの研究からは，ポジティブ感情 誘発時には, 大煩骨筋部 (Zygomatic major muscle region)活動が，ネガティブ感情誘発時には匆眉筋 部(Corrugator muscle region)活動が, それぞれ増 大寸ることが示されている。これらの知見は，広く 感情と運動反応の結びつきを示すものと考えるこ とができる。

一方, Neumann et al. (2005)は, fEMGの活動量 ではなく, fEMG活動の潜時に着目した研究を行って いる。彼らは, 感情価を持った刺激を参加者に提示 し，それに対してできるだけ早く指定された表情筋 を意図的に動かすことを求め, その際の潜時を測定 した。その結果, 提示された刺激の感情価と求めら れた表情筋反応の感情価が一致・対応寸る場合 (e. g. , ポジティブ感情誘発刺激に対して大煩骨筋を動 か寸)には，両者が不一-致の場合 (e.g. , 皺眉筋を動 かす)に比べて fEMGの潜時が短くなることが見出さ れた。さらにNeumann et al. (2005)は, この効果 は, 参加者が刺激を評価・判断しようとする意図が なくても生起するという意味で自動的なものであ ると論じている。彼らの知見は, fEMGの潜時も感情 や態度の指標となる可能性を示している。しかしな がら, fEMG潜時についての研究はあまり行われてい ない。

そこで本研究では, Neumann et al. (2005) と同 様, 刺激感情価が fEMG潜時に及ぼす影響を検討寸る ことを目的とした。

\section{1. 方 法}

\section{【実験協力者】}

成人男性18名 (平均 26.3 歳)

\section{【刺激と装置測定指標】}

刺激としてInternational Affective Picture
Systemより，ポジティブ刺激，ネガティブ刺激をそ れぞれ5枚, 計10枚を選出した。

fEMG測定には, 筋電図アンプ (TEAC, BA-1104-MA) を用い, 大项骨筋部および㱀眉筋部に電極を装着し て導出し，サンプリング周波数 $1 \mathrm{kHz}$ で計測した。

\section{【手続き】}

実験は，刺激が提示されたらできるだけ早く煩 (大㚘骨筋)を動か寸ことを求める笑顔条件と,でき るだけ早く眉(皺眉筋)を㱗めることを求める渋面 条件で構成され, 実施順序は参加者間でランダムと した。各条件に先立ち，合図に合わせて指定された 筋肉を動かす練習を 10 試行実施した。その後, 10 枚の写真を1回ずつ提示したものを1ブロックとし て, 計3ブロック実施した。参加者は, 刺激が提示 されたらできるだけ素早く指定された顔の筋肉を 動か寸よう求められた。本試行終了後, 今度は動か す表情筋を変えて, 再び練習と本試行を行った。全 ての実験終了後, 提示されたスライドの誘意性と覚 醒度について評定を求めた。

【分析方法】

fEMG信号については, フィルタ処理により瞬目や 体動の影響を除去した後, RMSを算出した。各刺激 について, 提示前 $1 \mathrm{~s}$ 間の平均とSDを求め, 平均 $+3 \mathrm{~S}$ Dを閯值として, 提示後のfEMG活動が閥值に達する までに要する時間を潜時と定義した。

\section{2. 結果と考察}

笑顔条件・渋面条件別に，ポジティブ刺激・ネガ ティブ刺激提示時のfEMG潜時を比較した。その結果, 笑顔条件では, ポジティブ刺激提示時の fEMG潜時 $(M$ $=401 \mathrm{~ms})$ は, ネガティブ刺激提示時 (M=419ms) よりも 短くなる傾向がみられた $(p<.10)$ 。一方, 渋面条件 では, ネガティブ刺激提示時 (M= $405 \mathrm{~ms})$ の方が, ポ ジティブ刺激提示時 (M=418ms) よりも短くなる傾向 がみられた $(p<.10)$ 。また， スライドの感情評定で は, ネガティブ刺激の方がポジティブ刺激に比べて より不快で高覚醒であると評定された $(p s<.01)$

以上の結果は, 概ねNeumann et al. (2005) と一致 するものであり，刺激感情価によって fEMG潜時が異 なること,さらに表情の部位によってそのパターン に違いがあることが示唆された。 
感情喚起画像の時系列提示に伴う感情変化に関する 検討

○野代美香 (広島国際大学大学院総合人間科学研究科) - 岩 城達也 (広島国際大学心理科学部)

\section{1. 研究の目的}

感情体験の要素には, 感情の種類, 強さ, そして 時間的変化がある。たとえばストレス状況など，不 快感情が喚起された場合, 快刺激を求めることで不 快状態を緩和したり，逆に心地よい状態であっても 不快刺激が与えられることで気分を害したりするこ とがあり, 私達は感情の変化を日常的に体験してい る。特定の感情状態から別の感情状態へ遷移を考え た場合，この過程には感情の時間的特性と感情の支 配性が関連していると考えられる。そこで, 本研究 では，異なる感情喚起刺激を提示することにより

感情変化を引き起こし, その際に生じる快不快感情 の主観強度の時間的変化を検討した。なお，不快高 覚醒状態を基準に設定し，これに感情喚起なる画像 刺激を組み合わせて提示することにより変化する感 情の評価に注目した。

\section{2. 方法}

実験参加者: 大学生 14 名（男性 10 名, 女性 4 名, 平均年齢 23.9 歳）を対象とした。また, 脳波分析で はこの内の 10 名の測定結果を使用した。

画像刺激: 感情喚起画像集 (IAPS) (Lang, Bradley \& Cuthbert，1999）から快不快軸及び覚醒軸の組み合 わせを考虑して 24 枚を選出した。

実験手続き：実験制御用ソフトを用いてコンピュ 一夕上に注視点を 15 秒, 先行画像刺激を 45 秒, 後 続画像刺激を 45 秒, 最後に再び注視点を 15 秒提示 した。参加者は最初の注視点から最後の注視点提示 終了までの間, 感情測定用のボリュームを用いて継 時的に評価した。これを 1 試行として画像の組み合 わせから 12 試行行った。

主観評価：各試行後には，質問紙により，先行・ 後続画像に対する各々の不快一快および覚醒感につ いて 9 段階で評価した。また, 後続画像により感情 に変化が生じたかどうかを 5 段階評価した。

生理計測：セッション中は脳波, 心電図及び皮膚 コンダクタンスを継続的に記録した。脳波は頭皮上 21 部から中心部を基準に記録した。また, 第 I 誘導
により心電図, 非利き手第 2,3 指から皮膚コンダク タンス水準 (SCL) を記録した。各指標は $500 \mathrm{~Hz}$ で $\mathrm{A} / \mathrm{D}$ 変換した後, 脳波はスペクトル解析, 心電図は RR 間隔から瞬時心拍数を, SCL は水準変化を求めた。

\section{3. 結果と考察}

Fig. 1 は，不快高覚醒を喚起する先行画像に，後 続画像を組み合わせた条件において，継時的に記録 した主観的感情強度の変化を例示している。先行, 後続に関らず画像が提示されると 5 秒以内に急激な 変化が起こり, その後は一定水準を推移している。 また, 組み合わせ条件毎に, 変化の大きさを比較し てみると, 組み合わせ画像が不快の場合は, 同水準 を維持 (低覚醒) するか, さらに不快方向への評価 が高まった (高覚醒)。一方で, 快場合は, 高覚醒よ りも低覚醒の方が顕著に快方向への評価が高くなっ た。このことは, 快不快評価においても覚醒感が影 響することを示しており，不快感情を低下させるた めの快刺激の付与には，ただ単に快というだけでな く, 刺激のもたらす覚醒次元の変化も重要であると 考えられた。生理指標では，心拍数や皮膚コンダク タンス水準の自律神経系指標は, 組み合わせ条件に 関係なく，一方向的に低下する傾向を示した。この ことは実験セッションの進行に伴い覚醒が低下した ことを表しており, 生理反応からは画像提示の効果 は強くないと考えられた。一方で，脳波の $\alpha$ 帯域振 幅は, 不快高覚醒画像に伴い低下, 快低覚醒性画像 に伴い上昇する傾向を示し，画像が少なからず覚醒 水準に影響をしていることを示した。同様に前頭部 の左右差指数をみると, 快低覚醒条件で左活性が生 じている可能性があった。

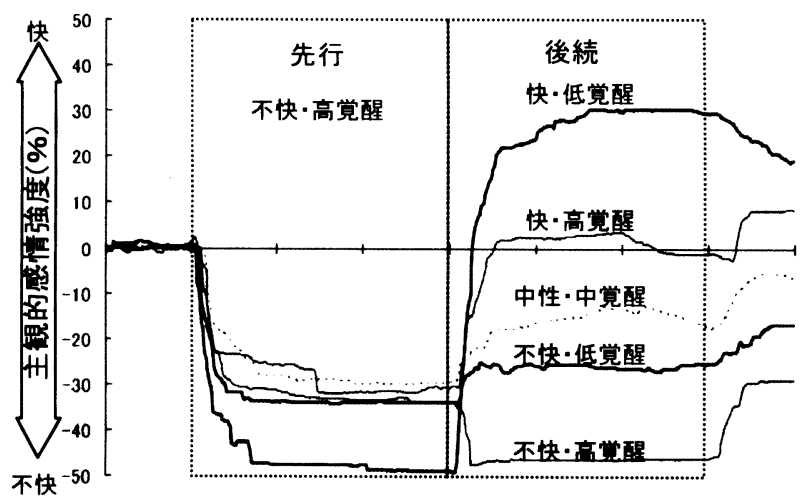

Fig.1 画像提示に伴い変化する主観感情強度の例 


\section{不確実な情動刺激に対する心臓迷走神経活動}

$\bigcirc$ 村上裕樹（日本学術振興会・名古屋大学大学院環境学研究 科) - 大平英樹 (名古屋大学大学院環境学研究科)

\section{【目的】}

情動刺激は注意を捕捉しそれに伴いさまざまな生 理反応が引き起こされる。これらの反応が環境への 適応を可能にしている。刺激呈示直後に引き起こさ れる心拍定位反応もそのひとつであり，多くの研究 で不快な画像が呈示された直後に心拍が一時的に減 少することが確認されている(Bradley et al. , 2001）。しかしながら, 心拍定位反応は刺激の感情価 によってのみ規定されるのではなく，不快刺激に対 する予期によっても生じることが示唆されている。 Polli ら (2007) は不快刺激と中性刺激を呈示する直 前に刺激の特性を知らせる手がかり（キュー）を呈 示した。その結果, 中性刺激に比べ不快刺激呈示後 の心拍はより減少したが, 刺激呈示前の心拍減少に は違いが見られなかった。Waugh ら（2008）は同様の 条件に加え不快刺激と中性刺激のどちらが呈示され るかわからない不確定キューを用いて感情状態の変 化をとらえた。その結果, 中性刺激が呈示されると 事前に知らされた条件に比べ，不確定キュー後に中 性画像が呈示された条件ではよりネガティブになる ことが示された。これは不確定キュー後の中性刺激 に対してより心拍定位反応が生起していることを示 唆している。本研究では Waugh ら（2008）と同様の条 件を用い, その際の心拍定位反応の挙動を確認する。

\section{【方法】}

被験者: 大学生·大学院生 24 名 (男 13 名, 女 11 名 平 均年齢 21.7 歳)

指標 : STAI-T, 心拍定位反応：刺激呈示後の心拍か ら刺激呈示前の心拍を差分し，刺激呈示後 3 秒間の 心拍減少のピーク值を算出。 刺激: 中性画像 40, 不快画像 20 枚を IAPS より選出。 手続き：シールドルームにおいて電極装着後, 全体 的な手続きと刺激呈示のルールを被験者に説明し， 質問紙への記入を求めた。不快刺激やその予期に対 する反応性の違いを検討するため $\mathrm{S} 1-\mathrm{S} 2$ パラダイム を用い，約 15 分間実験を行った (Fig. 1)。まず，確 定キュー（ $\triangle: 33 \% ）$ か不確定キュー（ $\nabla: 66 \%)$ を 1 秒間呈示。 5 秒後に画像を 1 秒間呈示した。確
定キューの後には必ず中性画像を呈示し，不確定キ ューの後には $50 \%$ の確率で不快画像か中性画像を 呈示した。10 秒後次の試行に移った。確定キュー後 の中性画像 20 回, 不確定キュ一後の不快, 中性画像 各 20 回呈示した。

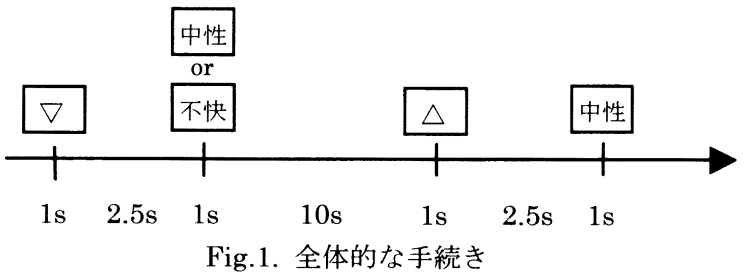

【結果と考察】

各被験者の各条件における心拍減少のピークを 分散分析したところ，確定中性刺激に対する心拍定 位反応が他の 2 条件に比べ小さかった $(F(2,46)=$ $\left.7.85, p<.005, \eta p^{2}=.25\right)$ 。これは不快な状況に直 面する可能性がある場合は，実際に不快な事象が生 起するかに関わらず，その刺激に注意を向けること によってリスクに対処するという環境への適応行動 を示している。さらに，各条件における各被験者の 心拍減少と各被験者の特性不安の相関分析を行った ところ, 不確定不快刺激に対する心拍定位反応にお いてのみ特性不安との負の相関を示した $(r=-0.41$, $p<.05)$ 。これは特性不安の高い人は不快な刺激によ り注意を配分するという知見に合致するものである。

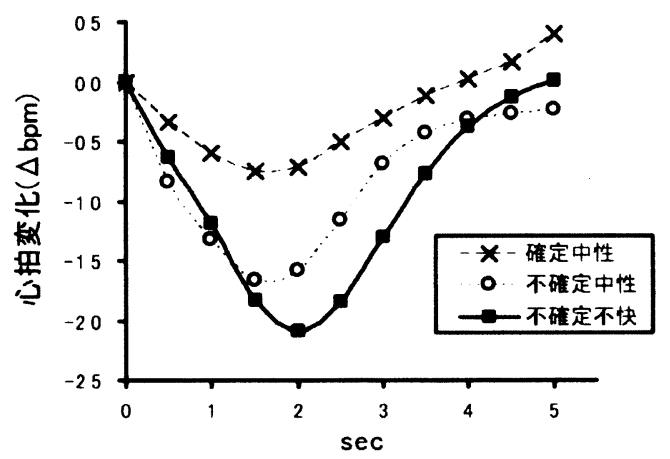

Fig.2. 各条件における心拍定位反応

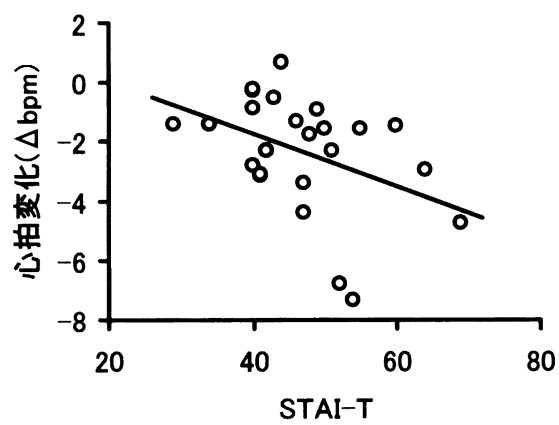

Fig.3. 不確定不快刺激に対する心拍定位反応と特性不安 との関連 
生 理 心 理

情县に伴う心腊血管系反応パターンの分析

○寺井 堅祐 (福井赤十字病院ストレス心療科)

梅沢 章男 (福井大学教育地域科学部)

\section{1. 目的}

我々はこれまで映像刺激で誘発した快一不快情動が 呼吸・心臟血管系に及ぼす影響について検討してきた. 具体的には，呼吸系はいずれの情動変化に対しても促 進性変化を示すため快一不快情動の違いを反映しない が，心臓血管系では快情動に比べて不快情動において 心拍数と平均血圧がともに増加することを明らかにし た（梅沢・清水，2003）. そこで本研究では，快一不快 情動にともなう生理反応パターンの差異について更な る検討を加えることを目的とした，具体的には，心臟 迷走神経活動の指標である心拍変動と動脈圧受容体反 射感度（Baroreflex Sensitivity：BRS) を測定した。

\section{2. 方法}

実験参加者: 健康な男女大学生 19 名 (年歯 20-24 歳). 映像刺激 : 情動を喚起するため, 市販されている洋画 ビデオ作品から, 快感情を引き起こす映像刺激（POSI） 3 本と, 不快情動を引き起こす映像刺激（NEGA）を 3 本, さらに中性刺激（NEUT）を加えた計 7 本を作成し た. 各刺激の長さは, 約 5 min に編集した。

手続き : $20 \mathrm{~min}$ の安静測定 (PR) の後, POSI, NEGA, NEUT の計 7 本をランダムな順序で呈示した. 各映像刺 激の間には，約 $5 \mathrm{~min} の$ 休息時間を設けた。

測定指標 : 心電図は標準第 II 誘導で導出し, 動脈血圧 は非利き手第 2 指に装着したカフ（オメダ社 Finapres2300）を用いて連続記録した．心拍変動はFFT 法により高周波数成分 $(\mathrm{HF})$, 低周波数成分 $(\mathrm{LF}), \mathrm{LF}-\mathrm{HF}$ 比（LF/HF）を算出した. BRS は伝達関数法により推定 した. なお, 心拍変動と BRS の分析にはWinCPRS (Absolute Aliens 社) を使用した.

分析方法 : POSI, NEGA は, それぞれ 3 本の刺激呈示中 の平均值を求めて代表值とした. また映像刺激の前半 と後半は, 各映像刺激の中間点をもとに折半した.

\section{3. 結果と考察}

PR, NEGA, POSI における心拍数 (HR), 平均血圧 (MBP), BRS の值を Fig. 1 に示した. HR は, PR に比べて NEGA で約 2 bpm, POSI で約 3 bpm 減少していた. MBP は, PR に比べて NEGA で $8 \mathrm{mmHg}$, POSI で $5 \mathrm{mmHg}$ で上昇し
ていた.また BRS は, PR に比べて NEGA で $1 \mathrm{msec} / \mathrm{mmHg}$, POSI で $3 \mathrm{msec} / \mathrm{mmHg}$ 増加していた. 条件(PR/NEGA/POSI) を要因とした分散分析を施した結果, 3 測度ともに有 意な主効果を認めた。 下位検定の結果, HR では POSI が PR を有意に下回り，MBP では NEGA と POSI がともに PR を有意に上回る值を示していた. また BRS では, POSI と NEGA がともにPR を上回り，さらにPOSI では NEGA を有意に上回った，以上の結果より，HR は快情動のみ で低下するが, MBP と BRS は快一不快情動の両方で増 加することが示唆された. さらに BRS 増加は, 不快情 動に比べ快情動で著しいことが明らかにされた。

BRS で観察された情動性の反応パターンが一過性か 持続性かを検討した.PRからの変化量を算出して, POSI, $\mathrm{NEGA}$ ごとに前半と後半の值について比較を加えたとこ ろ，いずれも有意差を認めなかった (NEGA： t (14)=.72； POSI : t $(15)=1.81)$. 情動刺激にともなう BRS の変化は, 快一不快ともに刺激の前半から後半にかけて安定して 出現していたと考えられる.

次に課題中の心拍変動変化について検討した. HF, LF, LF/HF について条件（PR/NEGA/POSI）を要因とし た分散分析を施した結果, HF のみで有意な主効果を認 めた. 下位検定の結果, NEGA が PR に比べて有意に低 い值を示していた. 以上より，心拍変動解析の結果に は, 快一不快情動の違いが反映されないと考えられる。

本研究の目的は, 映像刺激により惹起された快一不 快情動の差異が自律神経指標に現れるかどうかを検討 することである.MBP と BRS は情動全般の変化を反映 するが，とくに BRS を測定することで快一不快という 情動の質的な違いをも検出可能であると考えられる.

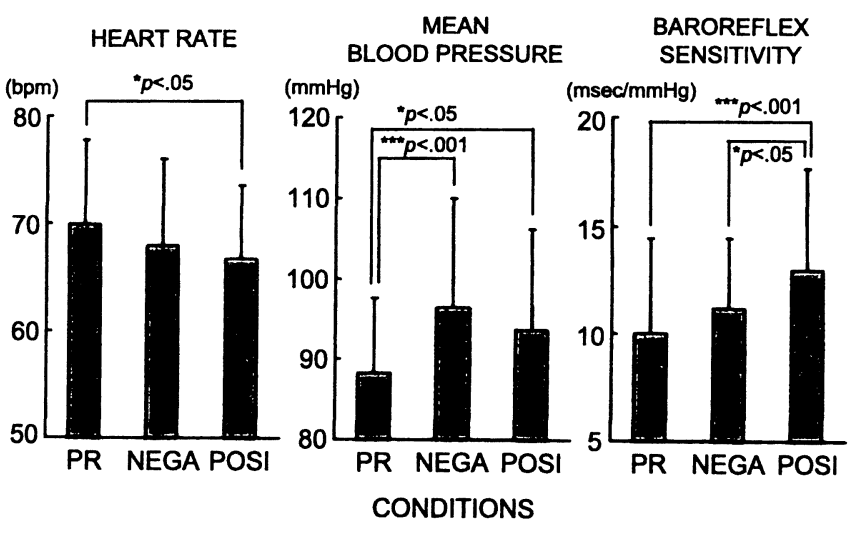

Fig. 1 安静と映像呈示時の HR, MBP, BRS 変化 （本研究の一部は科学研究費（課題番号 15300273）の 補助を受けた） 


\section{記憶とストレス反応性の関係}

○松村健太 (国立精神・神経センター 精神保健研究所) ・ 澤田幸展（札沅医科大学 医療人育成センター）

\section{目 的}

ストレスフルな経験に対寸る記憶の増強は生物の 生存にとって不可欠なことである（Maheu et al., 2008)。実際，ストレス刺激によって誘発される生 体内の変化（覚醒度の上昇, アドレナリン, コルチ ゾールの分泌）は，記憶を増強する働きを持つこと が示されている (Hamann, 2000; McGaugh, 2000)。 より近年では, 記憶時の生理的覚醒度の指標として 自律神経系活動を記録すると，これと記憶成績とが 相関することが示されている (Abercrombie et al., 2008; Nagamine et al., 2007)。しかしながら, 情動 価の異なる刺激を一方的に提示するという従来の典 型的な実験パラダイムは，ストレスと表現できるほ どまで強い刺激とはいえない（ほとんど心拍は上が らない)。そこで, 本研究では, 非常にストレスフル な能動的対処課題 (Obrist, 1981; 松村・澤田, 2004; 2006；2009）を実施し，この際に誘発される心臟血 管系反応と, 課題に関寸る記憶成績との関係を調べ ることにした。

\section{方 法}

参加者 : 健康な女子大学生 40 名が， $5 \sim 6$ 人から 成るグループ単位で参加した。ただし， 3 名の測定 に失敗したため, 最終的に 37 名（18.4 \pm 0.6 歳）を 分析の対象とした。

課題 : 競争型創作スピーチ（記憶）課題を用いた。 6 分間の課題実施中は, 1 分毎に置き換わる 3 つの 名詞を縌に並べて提示した $(3$ 個 $\times 6$ 分間で計 18 語)。実験参加者が行うことは, コンピューター画面 に提示される 3 つの名詞を全部使って, 面白くかつ 創造性に富んだスピーチを行い続けることであった。 スピーチを全て録画し，最後にこれに基づいてグル 一プ内でお互いを評価し合い，優秀であった者上位 2 名には 200 円，真ん中 2 名ないし 1 名には 50 円 の報酬を与える，という設定も施した。

条件 : 不快, 中性, 快の 3 条件を設定した。それぞ れの条件では，提示される 18 個の名詞全てが不快， 中性, 快のいずれかであった。ここで用いた名詞は, 宮崎ら（2003）が感情価を明らかにした 263 語から
抜粋したものであった。

手続き：9 分間の順応区間に続く 3 分間を安静区間 とした。課題説明の後, 課題準備のために設けた 2 分間を予期不安区間とした。録画と報酬についての 説明を行った後, 課題を 6 分間実施し, 質問項目に 評定させた。課題終了 12 分後から 2 分間, 課題中に 提示された単語を自由再させた。

質問項且：課題中の, 不快, 快, 注意, 努力, 難易 度, コントロールについて 10 点満点で評定させた。 心路血管系指標：最高，平均，最低血圧，および， 心拍数を上腕力フ血圧計 (Dynamap 8100) にて 1 分毎に測定した。ストレス反応性は，スピーチ時か ら安静時の值を引いて算出した。

\section{結 果}

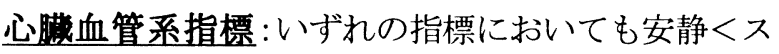
ピーチの主効果だけが認められた。

質問項且 : いずれの項目においても感情価の主効果 は認められなかった。

記憶成績 : 自由再生数, 誤答数のいずれにおいても 感情価の主効果は認められなかった。

記憶成績とストレス反応性 : 自由再生数と最高お よび平均血圧の反応性がそれぞれ， $r(36)=.42, p$ $<.01, r(36)=.35, p<.05$ で正に相関した。自由再 生数と他の反応性指標, および, 誤答数と反応性指 標の間には，有意な関係性が認められなかった。

\section{考 察}

記憶成績はストレス反応性と正に相関していた。 この結果は， $\triangle$ MHPG を用いた Southwick et al. (2002）の研究と一致している。

本研究で認められた関係性は最高および平均血圧 であった。これらの結果は, 課題遂行中の覚醒度, もしくは， $\beta$ アドレナリン系の充進が，記憶を増強 したことを示唆している。

本研究の着目点は反応性であった。そのため, 予 期不安や課題中の素値との関係を示す研究 (Abercrombie et al., 2008; Nagamine et al., 2007）とは，見ているものがかなり異なる。

本研究の反応性はかなり大きく, これと記憶の関 係性は課題終了 12 分後に既に認められていた。これ らの点は従来の研究と一線を画しているため, 本手 法は今後, 記憶とストレスの関係を探る新たな実験 パラダイムとして役に立つかもしれない。 
感情のリアルタイム評定法の妥当性の検討 その3 一評定の実施が「賞醒度」に与える影響一

○櫻井 優太 (愛知淑徳大学心理学研究科)

清水 遵 (愛知淑徳大学コミュニケーション学部)

\section{問題と目的}

感情あるいは情動の精神生理学的研究において, 生 理的指標データに対応する主観的感情体験の測度とし ては事後的に実施される心理尺度のデータが用いられ る。しかし，心理尺度は回顧的な指標であり，感情喚 起操作の時点で生じた感情を正確に反映していない可 能性があり，また，連続的なデータも得られない。そ こで, 櫻井・清水（2005）はジョイスティックを入 力装置とする感情のリアルタイム評定法を作成した。 本研究では, 感情喚起スライド呈示中の皮膚電気活動 とアラウザルチェックリスト（鄉式，2003）を指標 として, リアルタイム評定を課すこと自体が参加者の 覚醒水淮に影響をあたえるかどうか検討寸ることを目 的とする。

\section{方法}

参加者 大学生 30 名の参加を得た。

刺激 IAPS スライドセット (Lang et al., 2005) を用いた。Lang et al.の評定值（快適度）から， 「快」・「中性」・「不快」3 種のカテゴリーごとにそれ ぞれ 20 枚のスライドを抽出し, 合計 60 枚のスライ ドが用いられた。スライドは 1 枚あたり 5 秒間呈示 し，快・不快・中性のカテゴリーがそれぞれ 5 枚ご とに切り替わる合計 5 分間の一連の刺激系列を作成 した。スライドは，参加者の前方約 $60 \mathrm{~cm}$ の距離に設 置された 17 型液晶モニタの画面全体に呈示された。

感情リアルタイム評定装置 左右の両端に「快」・ 「不快」の凡例を表示した市販のゲーム用ジョイステ イックを使用した。スティックをそれぞれの方向に傾 けることで当該の感情を，スティックを中央にするこ とで中立感情を示すものとした。

生理指標 皮膚電気活動（SCL および SCR）と心 電図（HR）を測定した。

心理指標 主観的覚醒感を評定するためにアラウザ ルチェックリスト（卯式，2003）を用いた。

要因計画 リアルタイム評定の有無（評定群 : $n=$ 14 ・統制群 $: n=16$ ）を個人間要因として設定した。

手続き 参加者はまず 5 分間の安静状態におかれ,
生理指標の測定と前述のチェックリストによる覚醒感 の評定を行った。続いてスライドが呈示され，評定群 の参加者はジョイスティックを使用してリアルタイム に感情を評定した。統制群では評定を行わなかった。 両群ともスライド呈示中は生理指標の測定も同時にお こなった。 5 分間の刺激呈示が終了した時点で覚醒感 の評定を行った。

\section{結果}

各指標は安静時 (ベースライン) からの変化が算出 され，分析に用いられた。

生理指標 対応のない $t$ 検定によって群間の比較を おこなったところ，SCL および SCR，HR のそれぞ れの結果には評定群と統制群の間に有意な差異は認め られなかった。

心理指標 同様の検定をおこなったところ，活力ア ラウザルおよび緊張アラウザルともに有意な群間の差 異は認められなかった（Figure 1)。

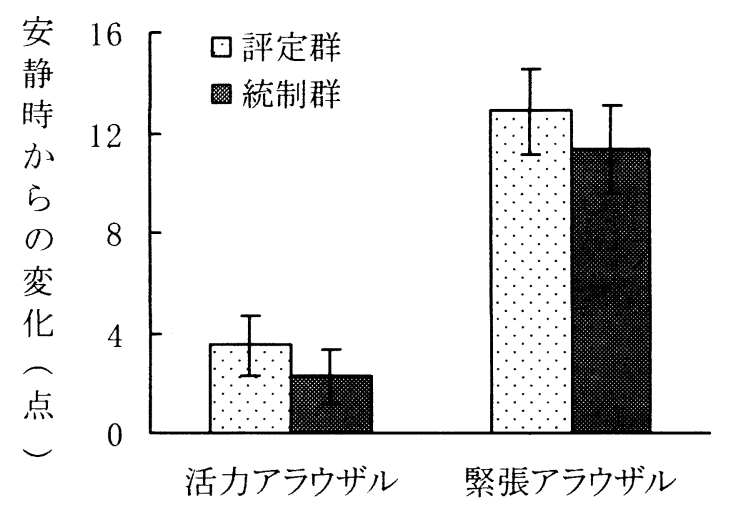

Figure 1. アラウザルチェックリストの得点

\section{考察}

皮膚電気活動，アラウザルチェックリストの各指標 において, 評定の有無による差異が検出されなかった ことから，本評定の実施は覚醒水準に対して大きな影 響は与えないことが分かった。覚醒水準が感情を構成 する重要な次元であることを考慮すれば，この結果は， 本評定法の実施自体が感情喚起に重大な影響を与えな いということを示唆する。すなわち，本評定法の妥当 性を支持する結果と言えよう。

今後はリアルタイム評定法の信頼性などについて検 討するとともに，リアルタイム感情評定のデータと生 理指標のデータを比較，分析するなど，種々の感情関 連研究に応用することが望まれる。 


\section{外的な表情现知と内的な行功モニタリングの}

相互作用 : 反応 ERN に基づいた検討

○板坦 俊 - 開一夫

(東京大学大学院総合文化研究科)

我々は他者の状況を知るために，その人の表情を見る ように，外界の情報は社会的・感情的情報を知る上で, 何らかの手がかりを我々に与えるものである。我々の 行為が良い・悪いという情報価を持つように，外界の 情報もそのような意味を持つことがある。本研究では, 行動モニタリング機能を反映するエラ一関連陰性電位 (ERN) をもとに, 外的な情報の認知と内的なモ二タリ ング機能がどのように関わるのかについて検討した。

\section{方 法}

【参加者】健常成人 12 名 (男女各 6 名)。

【課題】同一人物の表情を伴う顔刺激列で構成された フランカー課題を行った。参加者は水平に 5 つ並んだ 刺激の中心 (標的刺激) の顔の表情を弁別し，あらか じめ決められた刺激 - 反応マッピングにしたがって, できるだけ早く正確に左右の手の親指でボタン押し反 応を行った。

【刺激】ATR 顔表情画像データベース DB99 (ATR 社 製) から男女 3 名ずつを選び，それぞれの人物の怒り (Angry)・中立 (Neutral) ・笑顔 ( (Smile) の 3 種類の 顔表情刺激を用いて刺激列を作成した。

【手続き】 3 つの表情から怒り・中立 (AN 条件)，笑 顔・中立 (SN 条件) の表情を組久合わせた 2 条件を設 定した。各条件内で，標的刺激とフランカー刺激の一 致性 (一致・不一致刺激) を操作した。各刺激列は等 確率でランダム順に呈示した。各試行で顔刺激列を画 面中央に $200 \mathrm{~ms}$ 間呈示し, ボタン押し反応から 700 $1150 \mathrm{~ms}$ 後に次試行を開始した。タイムプレッシャー を $650 \mathrm{~ms}$ に設定し, 刺激列呈示時から $200 \sim 650 \mathrm{~ms}$ までの反応を分析対象とした。1 ブロックにつき 96 試行実施し，各条件で 6 ブロックずつ行った。

【記録】頭皮上 30 部位から鼻尖基準として, バンド パス $0.05-100 \mathrm{~Hz}$, サンプリング $500 \mathrm{~Hz}$ で $\mathrm{EEG}$ を 記録した。オフラインで Zero-Phase $30 \mathrm{~Hz}$ low-pass filter (12 dB/oct.) をかけた。刺激列呈示時を基準とし て, -100 ms から $500 \mathrm{~ms}$ までの ERP を算出し, 各 条件および刺激タイプに関して, 0-100 ms 間の平均 振幅を評価した。分析部位として 5 部位 $(\mathrm{Fz}, \mathrm{FCz}, \mathrm{Cz}$, $\mathrm{CPz}, \mathrm{Pz}$ ) を用いた。

\section{結果および考察}

【行動指標】各条件における正答率之反応時間 (RT) については, 従来のフランカー課題のように不一致刺 激に対する正答率の低下, および RT の遅延に関して, 統計的に有意な効果はなかった。

【ERP】各条件の反応を基準とした ERP の平均振幅 に関して, 反応 (正誤) $\times$ 標的 $(2$ 表情) $\times$ 刺激一致 性 (一致・不一致) $\times$ 電極 (5 部位) の 4 要因分散分 析を行った。刺激の一致性の効果はなかったものの, $\mathrm{AN}$ 条件, $\mathrm{SN}$ 条件ともに反応と電極の交互作用が有 意であり, 各条件において誤反応時に $\mathrm{Cz}$ 付近で陰性 電位 $(\mathrm{ERN})$ が生じたことを示した。また，両条件に おいて，標的と反応の交互作用が有意であった。単純 主効果を検封したところ， $\mathrm{AN}$ 条件では，誤反応時に 生じる ERN が怒り顔よりも中立顔に対して増大した。 一方, SN 条件では, ERNが中立顔よりも笑顔に対し て増大した。図 1 には，両条件において刺激一致性の 効果がなかったため，一致・不一致刺激を含めた標的 刺激ごとの反応時の $\mathrm{ERP}$ 波形を示した $(\mathrm{Cz}$ 部位)。 ERN は各条件において，相対的にポジティブな標的 表情に対して増大を示した。また，本研究では条件・ 刺激タイプによらず，動機付けの効果を付与していな い。したがって，内的な行動モニタリングは，外的な 刺激が持つ情報がポジティブか，あるいはネガティブ かという文脈と関わることが示唆された。エラーはネ ガティブな価値を伴うものであるため，外的な刺激が 相対的にポジティブなときにエラーを起こすことはエ ラーの顕著性を高める。つまり，行動モニタリングに は内的状況と外的状況の間にある情報価を照合する過 程が関与していることが示された。
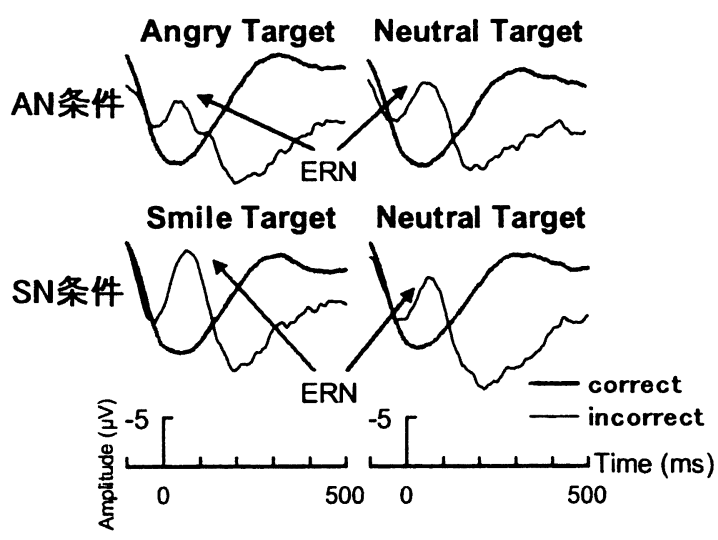

図 1. Cz 部位における反応時の総加算 ERP. 各条件の標的刺激を もとに, 一致·不一致刺激を含めて加算平均した。 


\section{自己顔プライミングを反映する脳波成分の個人差の 検討}

$\bigcirc$ 金山範明（東京大学大学院情報学環 - 日本学術振興会） 大平英樹 (名古屋大学大学院環境学研究科)

\section{1. 目的}

Jemel et al. (2005) は, 有名人の名前が呈示さ れた時のその顔判断に関する反応時間が, 関係のな い顔に比べて早まることを示した。これは，その人 が誰であるかという概念情報が名前と顔で一致する 場合にプライミング効果が起こることを示唆してい る。この効果がN400様の陰性成分に反映されたこと から，一種の意味プライミングの様相を呈している と考えられる。一方でよく知らない人の顔において は, 反復顔プライミングは起こるが, 名前一顔プライ ミングは起こらないことから，その人間の情報への 親しみが当該意味プライミング事態に重要であるこ とを示した。さらにこの効果は, 名前と顔の提示順 を逆にしても起こることや，自分の情報であれば顔 と付带情報（所属大学）の組み合わせでも起こるこ と (金山ら，2005，第25回生理心理学会発表)から， 対象の人物に対する情報統合の度合いを測る指標と なり得る可能性が示唆されている。

本実験では自己感が希薄であり, 自己に関する情 報統合が弱いと考えられている離人症性障害を取り 上げ，そのスクリーニングに用いられる質問紙によ って実験参加者を群分けし, 上記の顔一名前, 及び顔 一付帯情報プライミングが, 離人体験を多くするもの で減退するかどうかを検討することで，上記脳波成 分の自己感評価指標としての可能性を探る。

2. 方法

実験参加者 22 名 (女性 12名, 男性 10名, 年齢 18-21歳)の大学生健常者が参加した。参加者は全員 右利きであり，視覚異常を呈することはなかった。 全ての参加者において書面によるインフォームドコ ンセントが取られた。参加者は離人体験頻度質問紙 によって, 体験高頻度群 (H群 9 名), 低頻度群 (L群 13 名)に群分けされた。

刺激と装置 顔刺激は, DM-FVM100KS (Canon Inc.) により撮影, Photoshop7.0(Adobe Systems Inc)によ ってグレースケールで縦 $6.24 \mathrm{~cm} \mathrm{x}$ 横 $6.24 \mathrm{~cm}$ に加工 された。それぞれ未知顔 (男性, 女性各1枚), 自己
顔 (各参加者に作成) とし, 男性参加者には男性の未 知顔と本人の顔刺激, 女性参加者には女性の未知顔 と本人の顔刺激を呈示した。自己情報刺激は，それ ぞれの名前 (本人/未知), 所属 (本人の所属/他人の 所属）を呈示した。

実験計画 プライム (2水準: 自己顔/他者顔 $) \mathrm{x}$ タ 一ゲット（2水準：自己情報/他者情報） $\mathrm{x}$ 情報の 種類 (2水準 : 名前/所属大学)。

手続き 実験参加者は，ディスプレイから $60 \mathrm{~cm}$ 離 れた位置に座り(視角6.1x6.1度), 課題を行った。1 試行の流れは, Figure1の通りである。ターゲットの 文字刺激が自分に関連するかどうかを判断した。8 条件 20 試行, 計 160 試行を 1 ブロックとし, 休憩を挟 んで2ブロック行った。実験中は脳波キャップを装着 し, $\mathrm{Ag}-\mathrm{AgCl}$ 電極を 32 極, 基準電極は鼻尖, 抵抗值は $5 \mathrm{k} \Omega$ 以下，0.1-120 Hzのフィルタ， $500 \mathrm{~Hz}$ のサンプリ ングレートで脳波測定が行われた。眼電は外側眼角 よりモニタされた。

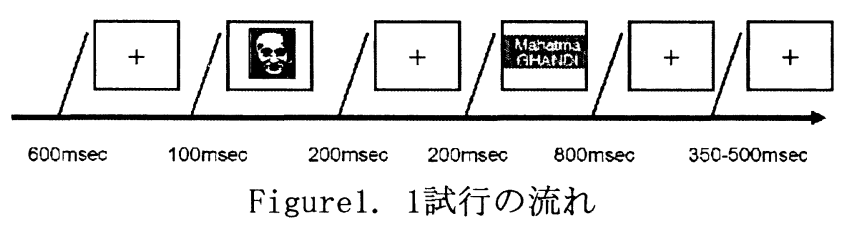

\section{3. 結果と考察}

反応時間から，自己情報に関して，L群では顔一名 前, 顔一付帯情報のどちらの組み合わせでもプライミ ングが起こるが, H群では顔一名前でのみ起こること が示された。さらにJemel et al.（2005）に基づいて, 陰性電位 (200-400ms) の平均電位を検討した結果, 名 前についても付帯情報についても, L群で見られた一 致一不一致の差 $(p<.05)$ が，H群では見られなかった。
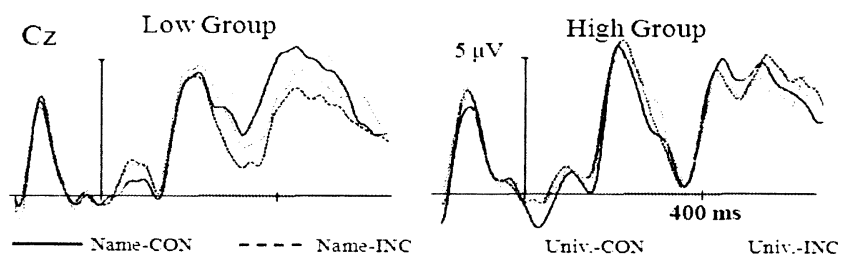

Figure2. 自己顔プライム条件での ERP 波形

これらの事から，自己顔プライミング事態において 出現する陰性電位は, 自己情報を緊密に保持してい るかという個人差を反映する可能性が示された。 


\section{表情認知における色彩の効果 一事象関連電位による検討一}

○今井章・\#小林みなみ・高瀬弘樹（信州大学人文学部)

\section{問題と目的}

表情には様々な個人情報が複合的に含まれ，コミュ ニケーション場面では他者の感情を判断するための 重要な情報源となる。この表情認知について, 事象関 連電位 (event-related potentials；ERPs)により検討 した研究は数多いが，表情に色を加えた研究は多くは ない。そこで本研究では, 実験 1 では白黒画像, 実験 2 では彩色画像を用いて, 線画の表情弁別における色 の影響を ERPs によって検討することを目的とした。

\section{実験 1}

\section{方法}

実験参加者 色覚および矯正を含め視力が健常な 大学生 8 名 (平均年齢 20.0 歳) が同意の下, 参加した。

刺激と提示方法 Yamada(1993)による線画のうち, “喜び”と“怒り”，“驚き”と“悲しみ”の表情図形 を組合せとして用いた。タキストスコープ(岩通 IS-703)によりオドボール課題の手続きで, “喜び-怒 り”と“驚き-悲しみ”の組合せを $4: 1$ の比率でラン ダムに提示した。1 試行は, 黒色背景のディスプレイ 中央に注視点刺激として+マークが $500 \mathrm{~ms}$ 提示され て開始され，注視点消去後に続けて表情刺激を視角 $3.3^{\circ} \times 3.3^{\circ}$ （観察距離 $80 \mathrm{~cm}$ ） で $300 \mathrm{~ms}$ 提示した。 その後, $1500 \mathrm{~ms}$ のブランク刺激を提示した。 50 試行 を 1 ブロックとして, 参加者には刺激と頻度の組合せ からなる 4 ブロックを 2 回ずつ計 8 ブロック施行した。

データの取得と解析 脳波は，国際式 10-20 法に基 づき, 前頭部 $(\mathrm{Fz})$, 中心部 $(\mathrm{Cz})$, 頭頂部 $(\mathrm{Pz})$, および 後頭部 (0z) から導出しサンプリング周波数 $500 \mathrm{~Hz}$ で, 刺激提示前 $200 \mathrm{~ms}$ から刺激提示後 $1000 \mathrm{~ms}$ までを収 録ソフト (EPLYZER-II)によりPCに記録した。

手続 電極装着後, 課題はディスプレイに提示され る表情が喜び, 怒り, 驚き, 悲しみのいずれであるか を判断し，ブランク刺激提示中にボタン押しによって 報告することであると参加者に教示した。本試行の前 に練習試行を 1 ブロック行い, 各ブロック間には 2 分 間の休止を挿んだ。

結果と考察 脳波は, 各部位, 各表情, および頻度ご とに加算平均された。その結果, 潜時 $150-250 \mathrm{ms,}$
250 - $350 \mathrm{~ms} ， 350$ - $550 \mathrm{~ms}$ に，陽性，陰性，陽性の各 成分が認められ，これらを P170，N2，P300 とした。 各成分を含む潜時帯の電位差を検討するため, 表情 $\times$ 頻度の分散分析を各部位ごとに行った。その結果, P170 では, $\mathrm{Fz}, \mathrm{Cz}, 0 \mathrm{z}$ で表情の主効果 $(F(3,21)=6.40$, $F(3,21)=5.25, F(3,21)=6.12, p<.05)$ が有意であった が，表情間に差はなかった。N2 では，Fz で表情の主 効果 $(F(3,21)=9.66, p<.05)$ が見られ(怒り>悲しみ), $\mathrm{Cz}$ で交互作用 $(F(3,21)=3.54, p<.05)$ が認められた (高 頻度：喜び $>$ 驚き，悲しみ; 低頻度：怒り>喜び)。 P300 では，表情による差異は認められなかった。

\section{実験 2}

方法 用いた刺激を除き，実験 1 と同様であった。 刺激 顔線画図形に付吅加える色は，大山・田中・ 芳賀 (1963) から, 喜びはピンク 5R/7.0/8.0, 怒りは赤 5R/4.0/14.0，驚きは黄 $6 \mathrm{Y} / 8.5 / 12.0$, 悲しみは青 1.5B/4.0/9.0 を選定した。条件として, 表情と色のイ メージが一致する “色一致条件” と, 表情と色のイメ ージが不一致の “色不一致条件”を設定した。

結果と考察 実験 1 と同様の成分が認められ，P170, N2, P300 とした。各成分を含む潜時帯の電位差を検討 するため，表情 $\times$ 頻度 $\times$ 色条件の分散分析を行った。 その結果, P170 では, $\mathrm{Fz}, \mathrm{Cz}$ で表情の主効果 $(F(3,18)=$ 3. 18, $F(3,16)=6.12, p<.05)$ が有意であった $(\mathrm{Fz}, \mathrm{Cz}$ : 怒り>悲しみ)。0zにおいては，表情と色の交互作用 $(F(3,18)=7.47, p \ltimes .05)$ が認められた(色一致：怒り> 悲しみ>喜び)。N2では，表情における有意差は認め られなかった。P300では，Fz，Pz，Oz で表情と頻度 の交互作用 $(F(3,18)=3.89, F(3,18)=10.20 ; F(3,18)=$ $4.46 ， p<.05)$ が見られた。下位検定の結果，特定の表 情における低頻度提示時に陽性方向に電位が増強す る傾向にあることが認められた。

\section{まとめ}

表情の弁別は，実験 1 では N2 で，実験 2 ではP170 で行われたことが示唆された。すなわち，表情弁別が 色の付加によって早まったものと考えられる。

\section{文献}

大山正・田中靖政・芳賀純 （1963）。日米学生におけ る色彩感情と色彩象徵 心理学研究, 34, 109-112.

Yamada, H. (1993). Visual information for categorizing facial expression of emotions. Applied Cognitive Psychology, 7, 257-270. 


\section{表情への注目が顔刺激に対するNO-GO 電位に 及ぼす影響}

○高村真広・徳永智子・橋本 翠・梨和ひとみ・ 宮谷真人 (広島大学大学院教育学研究科)

感情的刺激を用いた GO/NO-GO 課題時には, 非 感情的刺激を用いた場合とは異なる脳領域が活性化 する(Shafritz et al., 2006)。したがって, 感情的刺 激に対して働く反応抑制過程は特異的であることが 示唆される。徳永他(2008)は, NO-GO 電位を指標 にして, 刺激の感情的情報に対する注意の有無が反 応抑制過程を変化させるか否かを検討した。顔刺激 に対する表情判断課題と性別判断課題を実施し, 課 題間で電位を比較した。しかし，いずれの課題にお いても有意な NO-GO 電位が出現せず, 明瞭な結果 は得られなかった。本研究では, NO-GO 電位の変 化を観察しやすくするために, 課題における反応許 容時間を短く制限し，大きな NO-GO 電位が惹起さ れる事態(Jodo \& Kayama, 1992)で実験を行った。

\section{方法}

実験参加者 矯正視力を含む視力の正常な 10 名 (男性 3 名， 21 - 32 歳) が実験に参加した。

刺激 男女各 5 名の怒り顔と笑い顔の写真を刺激 として用いた。そのうち, 男女各 1 名の怒り顔, 笑 い顔を 1 名の参加者に対して使用した。

課題と手続き 表情判断課題では, 刺激の性別に 関わらず，指定された表情が呈示されたときにのみ ボタン押し反応をするよう教示した。性別判断課題 では，刺激の表情に関わらず，指定された性の顔が 呈示されたときに反応するよう教示した。刺激呈示 時間は $800 \mathrm{~ms}$ とした。反応許容時間は $500 \mathrm{~ms}$ 開始値とし, 誤答率が $10 \%$ 程度となるように適宜調 整した。

脳波の記録と分析 脳波は, 銀・塩化銀電極キャ ップを用い，国際 10-20\%による 9 部位 $(\mathrm{Fz}, \mathrm{Cz}$, $\mathrm{Pz}, \mathrm{C} 3, \mathrm{C} 4, \mathrm{~T} 5, \mathrm{~T} 6, \mathrm{O} 1, \mathrm{O} 2)$ から鼻尖基準で 導出した。同時に, 水平・垂直眼電困および, 利き 手上腕の筋電困を双極導出で記録した。刺激呈示前 $200 \mathrm{~ms}$ から呈示後 $800 \mathrm{~ms}$ の区間の電位を条件別に. 加算した。

\section{結果}

性別判断課題, 表情判断課題における電位を GO
試行，NO-GO 試行ごとに算出した（Figure 1,2）。 刺激呈示後 200-300 ms の区間にGO試行と NO-GO 試行の波形に差が観察され, $\mathrm{Fz}$ において顕著であっ た。同区間の平均電位を NO-GO 電位の分析に用い た。性別判断課題の電位について, 性（男, 女） $\times$ 反応 (GO, NO-GO) の 2 要因分散分析を行ったと ころ, 反応の主効果が有意であり, NO-GO 試行の 電位は $\mathrm{GO}$ 試行よりネガティブであった（F(1, 9)=12.01，p<.01）。それに対して，表情判断課題に ついて, 表情 (笑い顔, 怒り顔） $\times$ 反応の 2 要因分 散分析を行った結果, 条件差は有意ではなかった。

\section{考察}

顔刺激を用いた GO/NO-GO 課題における NO-GO 電位は, 顔の性別判断を行った場合に比べ て,表情判断を行った場合に減衰した。この結果は, 顔刺激に対寸る反応抑制機能の特異性は，その刺激 の感情的側面に注意を向けた時に現れることを示し ている。

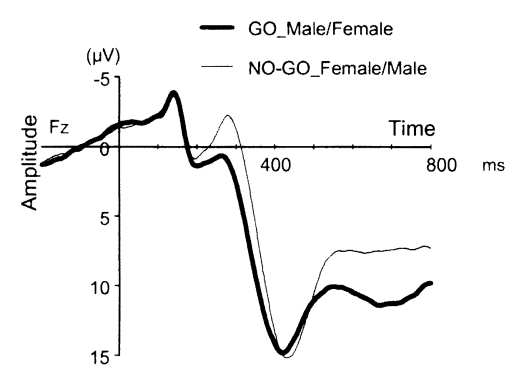

Figure 1. 性別判断課題における Fzの ERP 波形

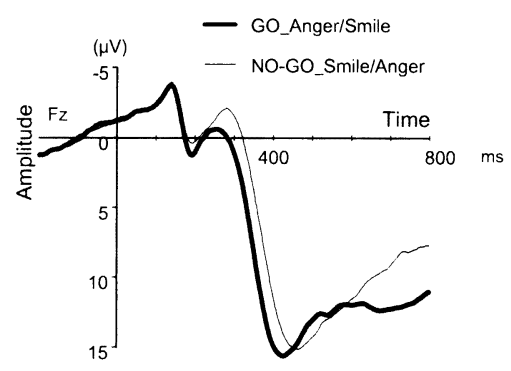

Figure 2. 表情判断課題における Fzの ERP 波形

\section{引用文献}

Jodo, E., \& Kayama, Y. (1992). Electroencephalography and Clinical Neurophysiology, 82, 477-482.

Shafritz, K. M., Collins, S. H., \& Blumberg, H. P. (2006). Neuroimage, 31, 468-475.

徳永智子 ・ 原 梢恵・衛藤 萌・梨和ひとみ・宮谷真人 (2008). 生理心理学々精神生理学, 26, 112. 
事象関連電位を用いた可愛らしさと現実感評価の試 み

○岩城達也 (広島国際大学心理科学部)

\section{1. 研究の目的}

幼体図式が可愛らしさ評価に関ることを調べる ために眼の形状操作を行った先行研究では, 眼の大 きさに可愛らしさを制約する範囲があり，さらに， 提示した画像が人工的である場合にはその制約が緩 くなること，つまりデフォルメを許容できることを 示した。そこで，今回は，犬の顔画像と自動車の正 面画像を, 制約条件の異なる生物と人工物カテゴリ として取り上げた。また，両カテゴリにおける制約 条件の違いは現実にマッチしているかどうか，現実 感が要因として介在している可能性があったので, 可愛らしさ評価に加えて現実感評価も行った。さら に,こうした刺激に伴う事象関連電位（ERPs）の 検討を試みた。

\section{2. 方法}

実験参加者：20 名の大学生を対象とした。 画像刺激: 生物画像として犬の顔, 人工物画像と して自動車を正面から撮影した画像を用意した。犬 画像では眼の大きさ, 自動車画像ではライトの大き さについて形状を維持したまま, サイズ比率を 5 段 階で変化させた。

実験手続き：PC ディスプレイに刺激画像を 1000 $\mathrm{ms}$ 呈示した。眼またはライトのサイズの異なる画 像を混合して，ランダムな順序で提示した。1つの 画像を 30 回提示したので, 合計 300 試行となった。 画像呈示が終わると, 呈示された画像について, 可 愛らしさ,もしくはリアリティを 5 段階で評価した。 可愛らしさとリアリティ評価は参加者間要因とし, 各群に参加者 10 名ずつを配置した。

記録と分析: $\mathrm{Cz}$ を基準として頭皮上 21 部位から 脳波を導出した。帯域通過周波数 $0.03-30 \mathrm{~Hz}$ で 増幅し, サンプリング周波数 $500 \mathrm{~Hz}$ で $\mathrm{A} / \mathrm{D}$ 変換し 記録した。記録後, 両耳架の平均電位で再基準化し た。刺激に同期して画像呈示前の $100 \mathrm{~ms}$ から刺激 後 $1000 \mathrm{~ms}$ を分析区間として加算平均処理を行い, 事象関連電位を得た。

\section{3. 結果と考察}

図 1 は，各画像における可愛らしさ評価（上図）
及びリアリティ評価（下図）の平均得点を示してい る。オリジナル画像である S3 を中心に, 逆 U 字の 関係を示している。また， 1 段階大きくしたサイズ も評価が高い。このことから, それぞれの評価に適 したサイズの範囲があることが分かる。一方で, 最 も大きなサイズの S5 では, 車に比べて犬画像の場 合は評価が急激に低下したことから, 生物と人工物 では最適範囲が異なり, 人工物の方が許容範囲は広 いと考えられた。可愛らしさ評価とリアリティ評価 の間に，明瞭な違いは認められなかった。

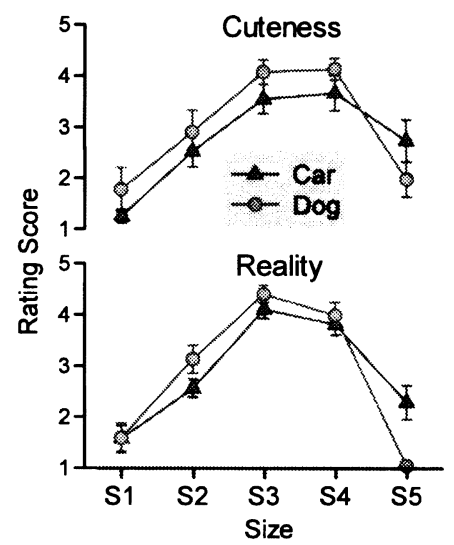

図1 可愛らしさ及び現実感評価得点

事象関連電位は, 刺激カテゴリ及び評価群を比較 条件として検討したところ, 潜時 $100 \mathrm{~ms}$ 付近に前 頭部を中心にした陰性電位（N1）と後頭部の陽性電 位 $(\mathrm{P} 1)$, 潜時 $170 \mathrm{~ms}$ 近傍に左右後側頭部由来の陰 性電位（N170）及び潜時 $200 \mathrm{~ms}$ 付近に頭頂部を中 心にした陽性電位（P2）を，全ての条件を通じて確 認できた。N170/P170成分では犬画像において可愛 らしいほど低電位であり，つまり非現実的あるほど 振幅は増加した。一方で P200 成分は犬画像が現時 的であるほど高振幅となった。得られた条件間の違 を図 2 にまとめてみると, 可愛らしさや現実感評価 が視覚処理における注意配分過程が深く関与してい ると考えられた。

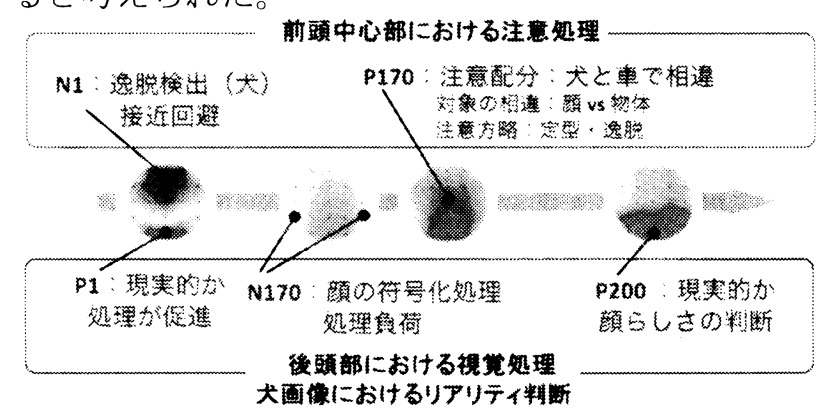

図2 各 ERP 成分における条件差の考察 
生 理 心 理

コミュニケーション技法が人間の感情に与える影響

\section{一主観的評価と客観的評価について一}

上野栄一

(福井大学医学部看護学科)

【目的】病院内の臨床では, 患者とのコミュニケー ションは信頼関係を構築することが重要である。看 護師は質の高い看護実践能力が求められる。コミュ ニケーション技法は, ヘイズらによれは，治療的技 法と非治療的技法があると述べている。また，ナイ チンゲールは，看護とは患者の消耗を最小限にする ことと述べている。また，治療的技法と非治療的技 法の主観的な評価と非治療的技法を用いた時の自律 神経系の両者評価に関する研究は看護領域では研究 されていない。本研究では, 看護師に対象に, コミ ユニケーション技法が人間の感情に与える影響につ いて客観的評価と主観的評価との関係について検証 した。

【方法】対象：総合病院に勤務する看護師 33 名。年 齢 37. $65 \pm 10.80$ 歳であった。手順 : 1 ) 被験者（看護 師）は, 病院内のカンファレンスルーム個室 4.5 畳 の部屋に入室する。2)パソコンの画面上で, 看護場 面を見ていただく。尚, 研究者は, 被験者から約 2 $\mathrm{m}$ 離れたところで，心拍数の計測をする（POLAR S810i、MemCalc を使用)。3)看護場面は, 看護師が 清拭をする場面であり，看護師が足を拭こうとする と, 患者から,「そんなとこ, 拭かんでよろしい」と 大声で怒られる場面が 2 回出てくる。被験者には,

第 1 回目の怒りの場面と第 2 回目の怒りの場面, 共 感的相互作用の起きている場面を連続してみてもら う(計 6 分)。被験者の左手首には, 電極を 3 ヶ所貼 付し心拍数を計測する。指標は, $\mathrm{LF} / \mathrm{HF}$ （交感神経 指標）を基に行った。一人の被験者の所用時間は 15 分である。主観的評価は半構成的インタビューを実 施した。倫理的配慮: 被験者の所属する施設長に, 研究者自らが, 出向き, 研究の趣旨と目的を説明し て研究の許可を得た。また, 被験者にも, 研究者自 らが出向き, 研究の趣旨と目的を説明し, 同意の得 た看護師に実施した。研究期間は平成 17 年 10 月〜 平成 20 年 12 月。

【結果】主観的評価では, 怒りの場面では驚きや不 快感が顕著であった。良い相互作用の生じている場
面（共感的理解）では、嬉しいという感情表現が多 かった。VAS を用いた怒りの場面での不快感の平均 值は, 共感的相互作用の生じている場面の方が有意 に減少していた（ $p<0.00001 ） 。$

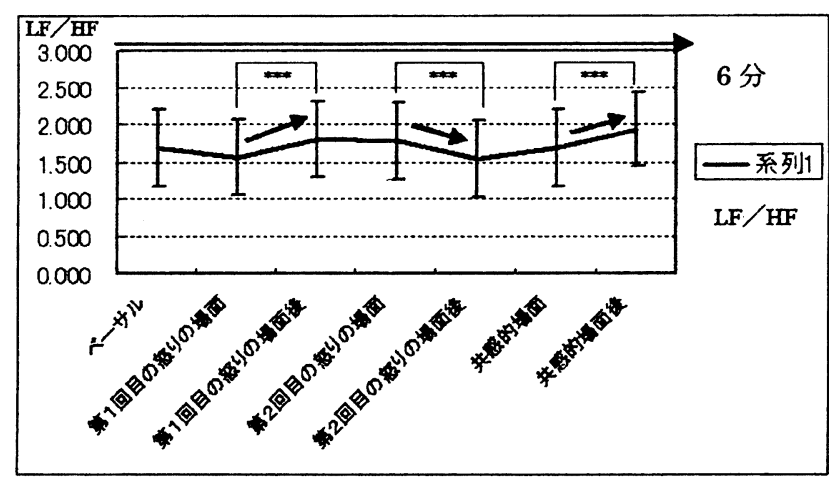

图1 怒りの場面から共感的相互作用の起きている時の交感神経の変化

次に客観的評価では, 1 回目の怒りの場面では, LF /HF は上昇した。また、2 回目の怒りの場面では, $\mathrm{LF} / \mathrm{HF}$ は， 1 回目に比較して交感神経活動の変化は ほとんどなく、徐々に減少していた。次に相互作用 の行われている場面では, 交感神経活動が有意に上 昇していた（図1)。

【考察】怒りの場面を主観的評価でみると，驚きや 不快感が生じていた。自律神経系についてみると、 第 1 回目の怒りの場面では, 交感神経系が有意に上 昇した。これは, 怒りが交感神経を上昇させたと推 察する。2 回目の怒りの場面で変化が少なく、徐々 に減少したのは，怒りに対する慣れが影響している と推察する。共感的態度をとっている場面をみると， 交感神経活動は有意に上昇していた。一般的にリラ ックスしている時は, 副交換神経活動が優位になる ことが知られているが, 本研究では, 逆の結果が出 た。これは, 最初に怒りの場面をみた看護師が, 受 容的態度で会話している患者の姿をみて, 驚いたと いう結果を反映した結果であると推察する。今後の さらなる検証をしていきたい。

【結論】1)怒りの場面では, 交感神経活動は有意に 上昇するが 2 回目の怒りの場面では，変化は少く、 徐々に減少した。2)良い相互作用の生じている場面 でも、交換神経活動は上昇した。3)副交換神経を上 昇させるコミュニケーションスキルは信頼関係を築 く上で重要な要素である。

(本研究は, 平成 17 年度富山第一銀行奨学資金を得 て行った研究の一部である。) 


\section{他者の笑い表情観察による表情同調と感情変化 一facialEMG, VAS，TEGを用いた検討一}

○渡辺有香（杤木県中央児童相談所）・松本秀彦·諸富隆 (作新学院大学人間文化学部)

\section{1. 目的}

他者の笑い表情観察によって観察者も笑い表情筋 活動パタンが自動的に引き起こされる「表情同調」 が生じる。顔面フィードバック仮説が正しければ, 笑い表情同調によって感情が快方向へ変化すること が予想される。さらに，笑い表情は微笑から強い笑 いまで様々であり，表情同調は笑いの強さを反映し た形式で惹起されるものなのかは明らかではない。

そこで本研究は，他者の笑い表情の強度に従った 形式で表情同調するのかどうかをfacial EMG（fEMG） 及び主観的感情評価によって検討することとし，性 格特性(TEG) との関連性の有無も検討した。

\section{2. 方法}

対象者：健常大学生14名（男性8, 女性6, 平均22歳）。 刺激 : 真顔と笑い表情を4人の平均顔から作成した。 FACSにより弱中強の3強度の笑い操作した。刺激は固 視点提示後, 真顔 $(750 \mathrm{~ms})$ に続き笑い顔 $(5000 \mathrm{~ms}$ 間）が提示された。試行数は72試行（4人物 $\times 3$ 強度 $\times$ 各6試行）でランダム提示した。サイズは $11 \times 13.5 \mathrm{~cm}$, 観察距離は $80 \mathrm{~cm}$ であった。課題1「笑い表情観察課 題」：被験者は提示された笑い表情刺激を観察した。 課題2「主観的感情評価課題」: 課題1の後, 12刺激に ついて一回ずつ主観的感情価をVASで回答した。課題 は課題1, 課題2の順で行った。記録手続き及び分析： fEMGは铍眉筋, 大煩骨筋, 眼輪筋から双極導出した （バンドパス $10 \sim 1000 \mathrm{~Hz}$ ，サンプリング周波数 $1 \mathrm{kHz}$ ）。 fEMGの積分值は笑い表情提示から0.1秒ごとに算出さ れ, 真顔刺激時のfEMG積分值で割り算した。VASは表 情別に各感情価のスコアを算出した。

3. 結果

課題 1 : 真顔への筋活動量に対する笑い表情観察時 の表情筋の変化量を変化比率として算出した。3つ の表情筋について 3 笑い強度 $\times 10$ 経過時間の分散分析 の結果, 眼輪筋で時間経過要因の主効果が認められ $(F(9,117)=5.208, p \propto .01)$ た(強度間の下位検定結果は n. s. )。各笑い強度における 3 表情筋 $\times 10$ 経過時間の分 散分析の結果, 中強度において交互作用が有意で
$(F(18,234)=3.014, p \times .001)$ ，笑い表情刺激提示 0.4 ～ $0.7 ， 1.0 \mathrm{~s}$ の区間で解眉筋よりも大㚘骨筋および眼輪 筋の方が変化比率は大きかった。また，大㚘骨筋に おいては0.7s以降, 眼輪筋においては $0.4 \mathrm{~s}$ 以降で $0.1 \mathrm{~s}$ 時点の変化比率よりも有意に大きかった。課題 2 ：6項 目 (幸福, 悲しみ, 怒り, 嫌悪, 恐怖, 驚き) $\times 3$ 笑い 強度の分散分析の結果, 交互作用が認められた $(F(10,130)=14.381, p<.000)$ 。下位検査の結果, 中強 度と強強度においては幸福項目が他の感情価より大 きくなった $($ 中: $F(5,65)=43.332, p \propto .000 ;$ 強: $F(5,65)=$ $42.970, p \times .000)$ 。また, 幸福項目においてのみ刺激 強度の増加に従って評価值が大きくなった $(F(2,26)=$ $23.101, p \ltimes .000 ; \mathrm{W}, \mathrm{M}, \mathrm{S}$ 各23.2, 42.6, 62.7)。性格特 性：TEGの優位得点がCP2名, NP4名, A1名, FC2名, AC3名であった。

4. 考察

以上の結果から, 中程度以上の強度の笑い表情観 察によって主観的快感情が喚起されることが示され た。また, 中程度の強度の笑い観察後, 眼輪筋, 大 煩骨筋活動が増加したことから, 同調反応が生じた ことが示された。また、眼輪笳においては表情呈示 後 $0.4 \mathrm{~s}$ で筋の活動量が像出していることがわかった。 したがって，笑い表情観察によって感情喚起及び表 情同調が生じることが明らかとなった。また，TEGに よる性格特性と同調反応とは関連性がなかったこと から，“共感性”などの特性との関連性の検討が必 要であろう。今後, 他表情についての検討, 刺激系 列の影響の確認, 表情筋活動の程度で分類し分析す ることも課題として挙げられた。
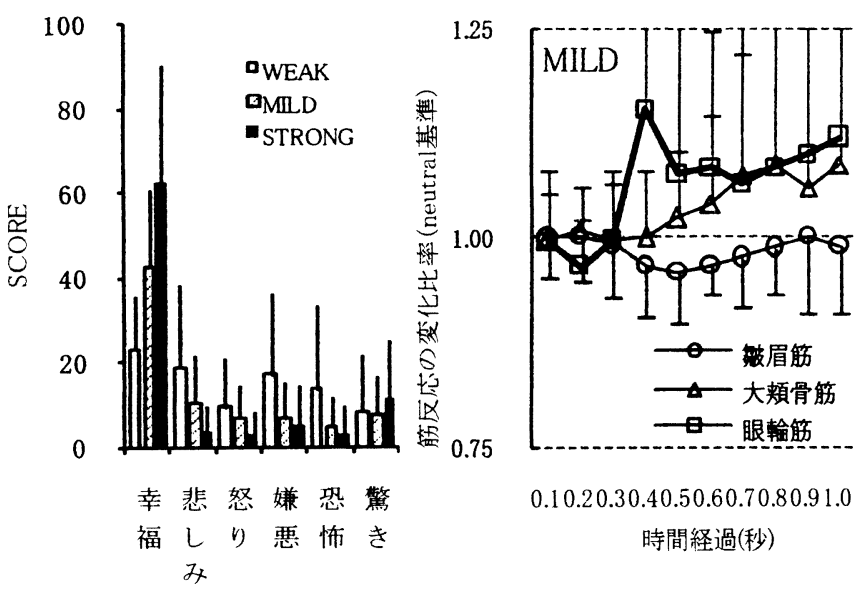

0.10 .20 .30 .40 .50 .60 .70 .80 .91 .0 時間経過(秒)

Figure 1. 笑い表情観察直後の主観的感情評価（左）と笑い 中強度における各表情筋反応の推移（右）. 
他者の存在が感情刺激処理に影響するか？： LPP による検討

\section{○野上 那佑多 ・ 開一夫}

(東京大学大学院総合文化研究科)

普段生活をしていると,同じような状況でも一人の 場合と他者がいる場合では感じ方が異なる場面が多々 ある。同じものを見ていても,一人で見る場合と二人で 見る場合では感じ方が変わるのではないだろうか。本 研究では, 他者の存在の感情刺激処理における影響に ついて,事象関連脳電位 (ERP) を測定し, 覚醒度の高 い刺激に対して, 振幅が増大する後期陽性成分（LPP） に基づいて検討した。

\section{方 法}

【参加者】健常成人 16 名（男性 9 名, 女性 7 名）。参 加者は,それぞれ同性の友人一名を同伴した。なお参加 者はそれぞれ友人間 liking 尺度（Fujiwara 1983）に 回答した。男性平均 $=78.78$ 女性平均 $=86.14$ (先行研究 では,男性平均=78.71 女性平均=80.23)

【課題】参加者は一人で, または同伴者と二人で感情刺 激を見て, その呈示刺激に対する快度指数を刺激呈示 後に毎回主観評定した。主観評定は, キーボードの上部 にある 1ー9の数字キーにあらかじめ両手の指を置き, 提示された刺激に対してポジティブな印象を持った場 合に大きい数值を, ネガティブな印象を持った場合に 小さい数值を押した。

【刺激】International affective picture system (IAPS) より快 (pleasant) 20 枚, 中立 (neutral) 20 枚, 不快 (unpleasant) 20 枚の計 60 枚のセットを 2 つ, 合 計 120 枚の画像を用いた。

【手続き】各試行で注視点を画面中央に $1000 \mathrm{~ms}$ 間呈 示し,その後刺激を $1500 \mathrm{~ms}$ 間呈示、再び注視点が $1000 \mathrm{~ms}$ 間呈示された後に主観評定を行い,瞬き用の 時間間隔を $1000 \mathrm{~ms}$ 間おき, 次の試行を開始した。刺 激は各セット内でランダム順に呈示した。1 ブロック 60 試行とし 8 ブロック行った。 2 ブロックごとに一人 条件と二人条件を入れ替えた。

【記録】頭皮上 32 部位から鼻尖基準として, バンド パス 0.05-100 Hz, サンプリング $250 \mathrm{~Hz}$ で $\mathrm{EEG}$ を 記録した。刺激呈示を基準として, - $100 \mathrm{~ms}$ から 1500 $\mathrm{ms}$ までの ERP を算出し, 刺激呈示後の $400-700$ $\mathrm{ms}, 700-1000 \mathrm{~ms}, 1000-1500 \mathrm{~ms}$ の平均振幅を評価 した。分析対象として正中線中心 $(\mathrm{Cz})$ を用いた。

\section{結果および考察}

【主観評定】人数（一人・二人条件）之感情価（快-中 立・不快）に対する評定值の 2 要因分散分析を行った。 評定值は, 快, 中立, 不快の順に有意に高く, 刺激の感 情価の操作が成功していることを確認した。いずれの 感情価においても,一人条件と二人条件の間に評定值 の差は見られなかった。

【ERP】正中線中心 $(\mathrm{Cz})$ から得られた ERP の 400 $700 \mathrm{~ms}, 700-1000 \mathrm{~ms}, 1000-1500 \mathrm{~ms}$ の成分に関し $\tau$, 人数 (一人・二人条件) $\times$ 感情価 (快.中立・不 快）の 2 要因分散分析を行った。どの時間空において も感情価の主効果, および人数 $\times$ 感情価の交互作用が 有意であった。中立, 不快画像に対しては,一人条件と 二人条件の LPP の振幅に差は見られなかったが,快画 像に対してのみ一人条件より二人条件の LPP の振幅 が減衰した。

主観評定では,一人条件と二人条件の間に差は見ら れなかったが,LPP の振幅は快画像に対して一人で見 た場合よりも二人で見た場合のほうが小さかった。こ れは二人で快画像を見た場合に,一人で見た場合より も覚醒度が下がることを表している。つまり,隣に他者 がいる場合は,その他者との意思の疎通なくただ座つ ているという事態であっても,快画像を見た場合に覚 醒度を抑制するプロセスが存在することを示唆してい る。

今回の研究により,行動反応には表れないが脳波に は表れるような感情刺激処理に対する他者の存在の影 響がある可能性を示すことができた。

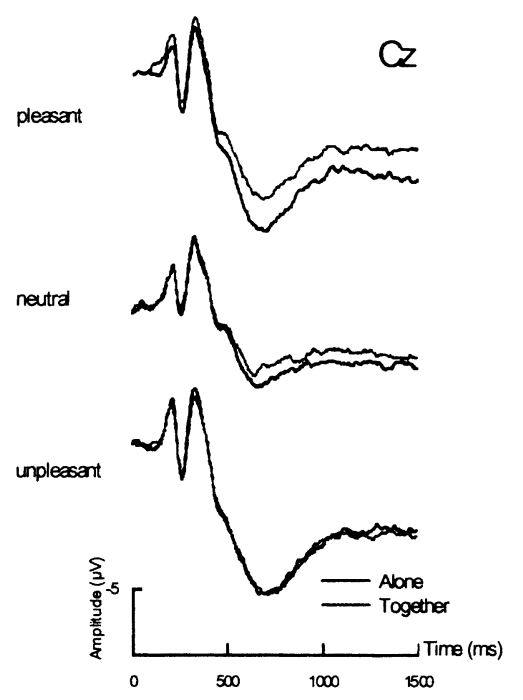

Figure 2. 一人条件および二人条件の総加算 $\operatorname{ERP}(\mathrm{Cz})$ 
対人不安特性亡他者の存在が

映像に対する面白さに与える影響 (1) 一自発性瞬目と唾液中アミラーゼからの検討一

○立平 起子・大森 慈子

(仁愛大学人間学部)

気分や感情は，そばに他の人がいるかどうかによっ て変化する。また，他者の存在によって生理反応も変 動する。写真呈示中の心拍は友人が横にいるときに低 くなり, 自発性瞬目は快な写真と不快写真に対しては, 友人がいるときのほうが減るが，中性の写真では変わ らない(林・大森, 2005)。

近年，他者との付き合いが上手くできないという兴 みを抱える人が増加している。対人不安の高い人は, 周りの目を気にし，どう見られるか恐れ，非難される のではないかと悩む。そこで，パーソナリティとして の対人不安特性と他者の存在に着目した。

本研究の目的は，他者の存在がコント映像に対する 面白さに与える影響を対人不安特性の違いによって検 討することであった。

\section{方法}

被験者: 大学生 18 名（男性 4 名, 女性 14 名), 平均 年齢は 18.2 歳(範囲 18-19 歳)であった。日本版 FNE 尺度 (石川他, 1992) の得点より, 高対人不安群 9 名, 低対人不安群 9 名の 2 群に分かれていた。

映像: $3 \mathrm{~min}$ のコント映像で, 笑えるコント 3 本, どち らでもないコント 3 本, 計 6 本を用いた。森林浴をテ 一マとした $2 \min$ のリラックス映像 6 本も使用した。

実験条件：同席する同伴者の有無により，他者あり条 件と他者なし条件の 2 条件を設定した。

記録指標 : コント映像視聴中の瞬目と笑い表情をビデ 才記録した。また，視聴前後の唾液中アミラーゼ活性 増加量を測定した。

手続き:リラックス映像呈示後, コント映像を視聴し, 映像に対する評定が行われた。映像視聴前後には唾液 採取を行い，これを 1 試行として， 2 試行を連続して 行い (session1), 2session が繰り返された。呈示され た映像は，笑えるコント，どちらでのないコント各 1 本であった。各 session は，他者あり条件または他者 なし条件で実施された。

\section{結果および考察}

Figure1に，各条件におけるコント映像視聴時の平
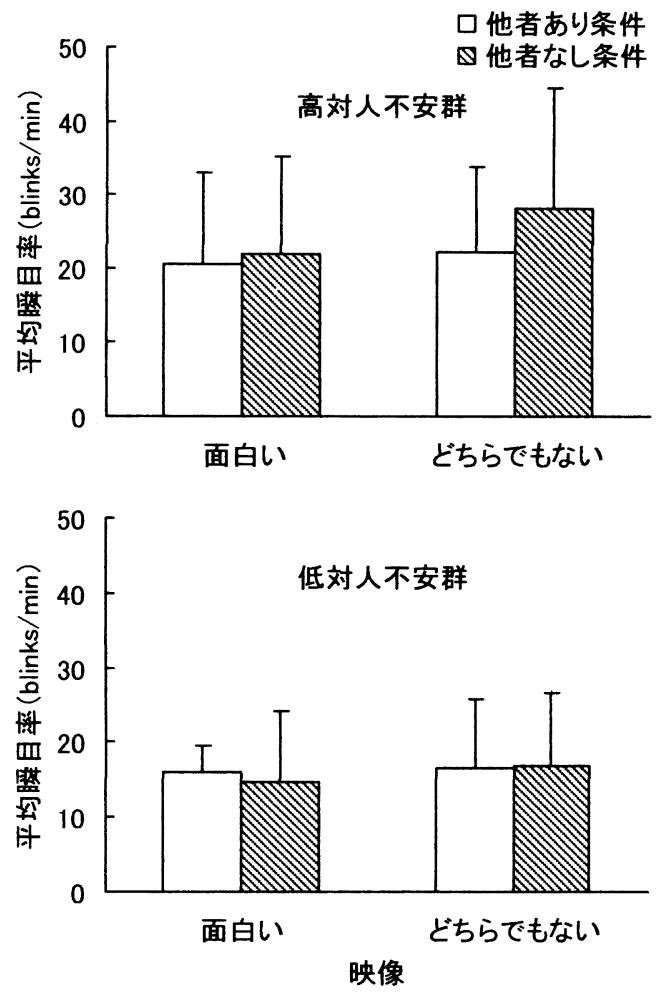

Figure1. 各条件におけるコント映像視聴時の平均瞬目率

均瞬目率を示した。群(2)×他者の有無 $(2) \times$ 映像 $(2)$ の 3 要因の分散分析を行ったところ, 映像の主効果が認め られた $(F(1,16)=10.84, p<.01)$ 。また, 群と他者 の有無の交互作用に有意な傾向がみられた（ $F(1,16)$ $=3.16, p<.10) 。 つ ま り$, 面白い映像よりもどちらで もない映像を見ているときのほうが瞬目率は高かった。 高対人不安群において，他者あり条件のほうが瞬目は 多く，他者あり条件，他者なし条件ともに，高対人不 安群のほうが低対人不安群よりも瞬目率が高くなった。 高対人不安特性者は, 過度の評価懸念が生じ, より 不安を感じていたと思われる。また，コント映像だけ でなく友人の反応に注意を向けていたため，他者がい るときに瞬目が抑制されたと考えられる。

以上, 本研究により, 他者の存在がコント映像視聴 時の自発性瞬目に与える影響が，対人不安特性の違い によって異なることが明らかになった。

\section{REFERENCES}

石川利江・佐々木和義・ 福井至 (1992). 社会的不安尺度 FNE SADS の日本版標淮化の試み 行動療法研究, 18, 10-17. 林優子 ・大森慈子 (2005). 他者存在が感情に与える影響一快 一不快視覚刺激呈示中の自発性瞬目と心拍による検討一 生理心理学々精神生理学(大会要旨), 23, 151. 
運動後に提示されるにおい刺激への情報付与が運動 回復過程に及ぼす影響

○満石 寿 (早稻田大学大学院人間科学研究科)

秋山優交京学院大学大学院人間学研究科)

長野祐一郎 (文京学院大学人間学部)

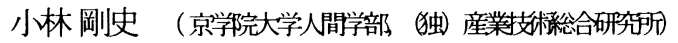

\section{問題と目的}

近年, 高強度運動能力の向上効果および運動後の 回復過程の身体的疲労の早期回復にアロマの吸引が ポジティブな影響を及ぼすことが示唆されている (Romine et al., 1999, Yano et al., 2007)。しか し従来の研究で使用されたにおいの多くは一般的に 親近性の高いにおいであり，一般的に親近性の低い においに対して情報内容を操作し, 運動後の回復過 程に及ぼす心理・生理的効果を検討した研究は現在 のところ皆無である。そこで本研究では，軽度の一 過性運動を行い, 運動後に吸引する一般的に馴染み の薄いにおいに対してポジティブな情報を付与し， 参加者の心理・生理的反応に及ぼす影響について検 討した。

\section{方法}

【参加者】男女各 6 名の学生 (平均年齢 $=21.73$ 才, $\mathrm{SD}=1.66$ )。

【におい刺激提示条件】におい刺激（アニスシー ド・オイル）を 2 秒, 空気 3 秒の計 5 秒を 1 試行と して全 120 試行。

【運動負荷】エアロバイクにおける一定負荷プログ ラム（男性 80 ワット，女性 60 ワット）。

【測定指標】心理的反応：におい刺激に対する感 覚強度, 快-不快度, 馴染み度。生理的反応: 収縮 期血圧, 拡張期血圧, 心拍, 心拍出量, 全末梢抵抗, 圧反射感度 (容積補償式指血圧計 Finometer で計測)。

【教示内容】ポジティブ情報付与群と中立情報付与 群を設定した。付与した情報の内容は，ポジティブ 情報付与群が吸引するにおいが運動後の回復過程に ポジティブな効果を与えること, 中立情報付与群は においそのものの情報のみを付与した。

【実験課題と実験の流れ】実験に先立ちインフォ ームドコンセントを行い, その後計測器を取り付け, 安静状態を 3 分間計測し, 運動を開始した。運動は, ウォーミングアップ 3 分・一定負荷運動 5 分・クー ルダウンを 1 分であった。運動後はにおいの情報付
与時間 (3 分) を含め安静状態（回復過程）を 13 分 計測した。心理的反応の評価は運動後に行った。生 理指標の計測は，実験中は左手に計測器を取り付け たまま行った。回復過程は，におい刺激提示装置を 用いてにおい刺激と空気を切り替えて提示した。

\section{結果}

【心理的反応について】におい刺激の感覚強度, 快・不快度, 馴染み度をそれぞれ従属変数と, 情報 付与（ポジティブ／中立）群の間で $\mathrm{t}$ 検定を行った ところ, 馴染み度においてのみポジティブ付与群が 有意に高かった。

【生理的反応について】収縮期血圧, 挔張期血圧, 心拍, 心拍出量, 全末梢抵抗, 圧反射感度の変化量 を従属変数として, 情報付与（ポジティブ／中立） $\times$ 運動区間（運動中／運動直後／回復期(1)／回復期 (1) /回復期(2)）の 2 要因分散分析（混合計画）を行 ったところ, 全ての指標で運動区間の主効果が有意 であった。

\section{考察}

本研究では，一般的に親近性の低いにおい刺激を 用いて同刺激にポジティブ，または中立情報を付与 し, 心理・生理的反応への影響を検討した。その結 果, 心理的反応においては, ポジティブ情報付与群 の方が相対的に同におい刺激を馴染み深く評価する ことが明らかになったが，これまで我々が報告して きた快・不快度への有意な影響は見られなかった。 感覚強度に有意な影響が見られなかったのはこれま での我々の知見と一致している。一方, 生理的反応 においては，におい刺激に対する情報付与の有意な 効果は得られなかったが，全体的な傾向として運動 中に収縮期血圧, 拡張期血圧, 心拍, 心拍出量は最 も増加し, 全末梢抵抗, 圧反射感度は最も減少した。

本研究で, 心理および生理的反応に顕著な情報付 与の効果が検出されなかった理由として，標本数が 少ないことが最大の要因として挙げられる。個人差 の大きな心臓血管系反応の統計的分析においても顕 著に影響していることが推測される。さらに運動後 の心臟血管系反応のベースラインへの回復が遅延す る傾向が見られたことから，におい刺激の吸引方法 および個人の呼吸周期制御の改善の必要も示唆され た。 
前額部積分筋電位及び積分脳波 $(\alpha+\theta)$ の非対称とキャンドルと白熱灯を混ぜた照明 のみによるそれらの減衰

○三谷惠一 ( I PU・環太平洋大学次世代 教育学部; ペガサスキャンドルとの共同研究）

・陽性ビデオ刺激・報酬試行・接近行動・ 幸福な気分で左半球 EEGが活性化し、陰性 刺激・罚試行・退避行動・うつで右半球 EEG が活性化する (Davidson, 1984,1995; Jacons \& Snyder,1996; Pizzagalli et al, 2002)。

・安静状態の顔面の血流と温度は、右の額 が左の額よりも高いことが判明し、情動表 出に影響を持つ交感神経系活動は左右の額 に均質に分配されているのではないことが 示唆されている (Benedicic,M., et al, 2006)。 血流は右 75.16AU（吸光度）左 60.53AU、 温度は右 $35.79^{\circ} \mathrm{C}$ 左 $35.46^{\circ}$ であり、左右 の額の微細血管による制御が異なる。

目的 実験室経験 2 度目の健康な女性の左 前額部 (Fp1) の積分筋電位(I EMG) と積分 脳波 ( I EEG $[\alpha+\theta]$ ) が右前額部 (Fp2) より有意に高いことを示し、4 分間の「キ ヤンドル十白熱灯間接照明」のみがそれら を更に減衰させることを示す。

方法 右利き手 22 歳 32 歳ペガサスキャ ンドル女子社員 10 名。冬季午後に室温 $22^{\circ}$ 湿度 50 空調室で “身・心の状態の評価・改 善システム”にて 10 秒平均出力した。電極 を装着して開始 1 分後に室内灯消灯し、そ の後 2 分間をベースライン BL とした。次 に「キャンドル十白熱灯照明(15Lux)」を 4 分間おこなった。アフターベースライ

ン:ABL として 2 分間計測を続け、前半の 1 分を ABL 1、後半の 1 分を ABL2 とした。
1 週間後同じ被検者に途中 4 分間を「白熱 灯間接照明 $(5.7 \mathrm{Lux}) 」$ 条件とし更に 1 週間後 に「蛍光灯照明(377Lux)」条件とした。

結果 (1) I EMG10 秒平均は、BLから $\mathrm{Fp} 1: 1755.8 \mu \mathrm{V}$ ・秒が Fp2:1607.3 より有意 に高い $(t=2.47, d f=9, p<.035)$ (2)左右差があ りながら相関は高い $(r=+.964 \quad(p<.001)$ 。 (3)「キャンドル十白熱灯」のみ Fp1（ $t=1.2$, $p<.25) \mathrm{Fp} 2 （ t=1.1, p<.30)$ も下降する。

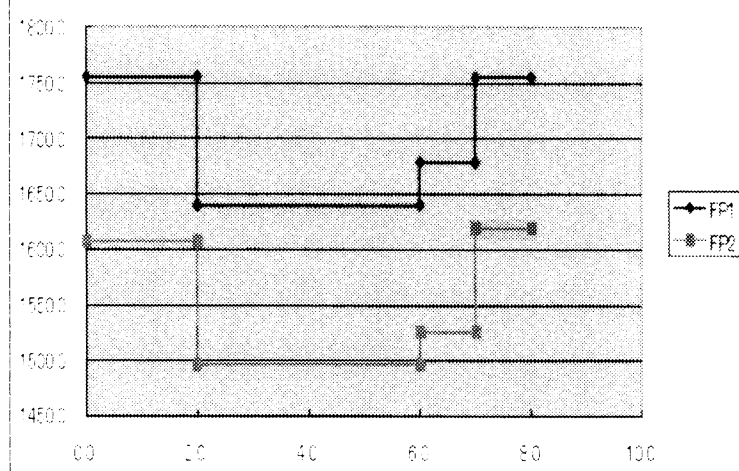

(4) I EEG $[\alpha+\theta 〕 10$ 秒平均も、BLから Fp1:195.5 が Fp2:171.9 より高い傾向にあ る $(t=1.2, p<.27)$ 。(5)左右差がありながら相

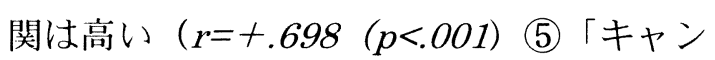
ドル十白熱灯」のみ $\mathrm{Fp} 1 （ t=1.6, p<.145)$ $\mathrm{Fp} 2 （ t=1.4, p<.21 ）$ も下降する。6白熱灯 間接照明と蛍光灯照明ですべてが上昇する。

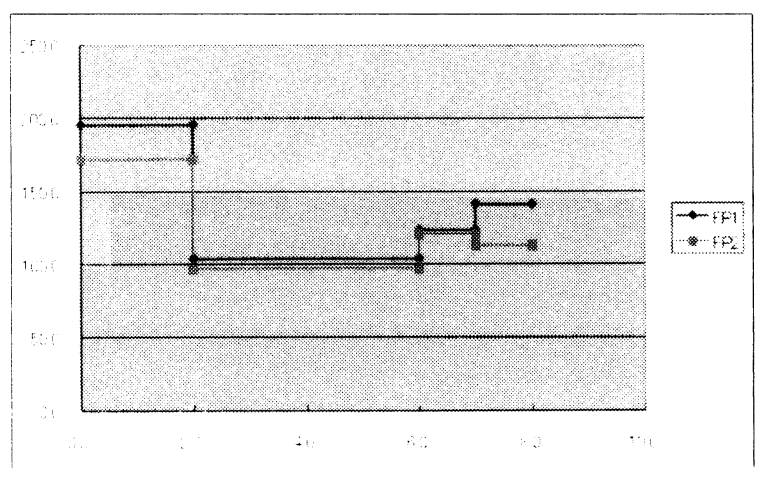

考察 実験公経験の無かつた 6 力月前夏季 の第 1 回実験の I EMG は BL から Fp1:2438.32<Fp2::2670. 18( $t=4.36, d f=9$, $p<.002)$ と逆、IEEGはFp1>Fp2である。 


\section{生 理 心理}

\section{壁面の三次元テクスチャが}

\section{仮想室内空間の雾囲気と視線の動きに与える影響}

○佐々木康成 ${ }^{1}$ ・森賢司 ${ }^{2}$ ・鈴木孝典 ${ }^{2}$ 饭東敏博

('同志社大学理工学部, “同志社大学工学部)

空間にはその雾囲気を形成する多くの情報が混在し ている。例えば, その空間の大きさ, 色, 位置, 仕切りな どは，空間が我々に与える心理的な印象に影響する。 なかでも, 室内空間の凹凹が形作る三次元テクスチャ は, 空間の䨌囲気に影響する大きな要因と考えられる。 本研究では, 空間のもつ壁面の三次元(3D)テクスチャ が空間の印象評価および視線の動きにどのような影響 を与えるか調べた。内壁面が凹凸の形作るテクスチャで ある空間をコンピュータグラフィクスで作成した仮想空間 によって実現し，実験1ではその空間にどのような印象 を持つか，また実験2ではその空間に対する視線の動 きがどのようになるか調べた。

\section{方法}

実験参加者 実験 1 では大学生 26 人 (男性 18 人, 女性 8 人), 実験 2 では同じく男性 8 人が参加した。

画像刺激 多様なパタンの二次元グレースケール 原画像の濃淡を高さに変換 $($ 白: $10 \mathrm{~cm}$ 一黒: $0 \mathrm{~cm}$ )して 16 枚の 3D テクスチャモデルを作成した。実験室の実空 間と同程度の大きさ(高さ $2.9 \mathrm{~m}$, 幅 $4 \mathrm{~m}$, 奥行き $8 \mathrm{~m}$ )の仮 想空間を設定し，このモデル空間に平坦な壁面である 基準壁面を配置したものを基準空間, 16 種の3D テクス チャをそれぞれ配置した空間を3Dテクスチャ空間とし， 合計 17 枚を画像刺激とした。画像刺激は実験参加者 の眉間から水平視角約 40 度となるようにスクリーン (120 インチ, 縦横比 4:3)に呈示した。

手続き 椅子に座った実験参加者の目の高さを床 から約 $100 \mathrm{~cm}$ に合わせた。実験 1では, 7 個の形容詞対 から成る評価項目それぞれについて, 画像刺激を順に 呈示し, 各画像刺激から受けるその空間の雲囲気を 7 件法で回答させた。なお, 基準空間の画像刺激は各評 価項目の最初と最後に 1 回ずつ呈示したため, 各評価 項目での試行数は計 18 試行であった。画像刺激を呈 示して印象評価する 5 秒間を 1 試行とし, 評価項目 7 個 $\times$ 画像刺激 18 枚, 計 126 試行行った。試行間間隔は 2 秒間とし, 基準空間の画像刺激を呈示した。画像刺激 の呈示順序は実験参加者間でランダムとした。

実験 2 では, 各画像刺激の空間の壁面テクスチャを
見ながら,その空間の持つ雾囲気を自由に思い浮か心゙ るように教示し, 視線追跡装置 (非接触アイマークレコ ーダ EMR-AT VOXER, ナックイメージテクノロジー)を 用いて実験参加者の視線の軌跡, 停留回数, 停留時 間, 軌跡移動方向, および瞬目回数について測定し, 解析を行った。各画像刺激呈示時間は, 基準空間が 60 秒, 3D テクスチャ空間が 30 秒とし, 呈示開始 30 秒およ び 5 秒の測定時間を分析対象とした。

\section{結果と考察}

実験 1 の各画像刺激に対する反応について, 各実験 参加者の平均評価尺度得点を基準とした得点について 主成分分析を行ったところ, 第 2 主成分までで 95\%以 上の累積寄与率があった。Table 1に示した各形容詞 対の因子負荷量から, 第 1 主成分を空間の「良好さ」, 第2主成分を空間の「面白さ」とした。画像刺激の主成 分得点の散布図を描いたところ, 第 1 主成分は $3 \mathrm{D}$ テク スチャパタンの明暗コントラストの強弱と関係しているこ とが推測された。第 2 主成分は $3 \mathrm{D}$ テクスチャの凹凸模 様の大きさやそのパタンの捉えや寸さが関係していると 推測された。

\section{Table 1. 各形容詞対の因子負荷}

\begin{tabular}{lrr}
\hline \multicolumn{1}{c}{ 形容詞対 } & 第 1主成分 & 第 2主成分 \\
\hline 落ち着きのある·落ち着きのない & 0.958 & -0.041 \\
開放的な·窮屈な & 0.922 & -0.164 \\
安堵感のある·恐怖感のある & 0.987 & 0.057 \\
面白いつまらない & -0.498 & 0.852 \\
安心な·不安な & 0.975 & 0.176 \\
快適な·不快な & 0.977 & 0.103 \\
好きな·嫌いな & 0.927 & 0.309 \\
\hline
\end{tabular}

実験2の各画像刺激に対する視線追跡の結果, 水平 方向に 14 分割した画像領域に視線が停留した回数を もとにその重心位置とばらつきを算出したところ, テクス チャパタンが大まかな画像では実験参加者間で視線の 重心位置のばらつきが小さい傾向にあった。

本研究では, 三次元のテクスチャパタンの内壁を持 つ仮想空間の心理的に評価と視線の動きとの関係につ いて調べたが, 画像解析や空間の雾囲気を表現する評 価尺度の構成について十分吟味していなかった。した がって今後は, 画像解析, 心理的評価と視線解析の結 果との統合を試みていかなければならい。また, テクス チャパタンは容易に符号化できない刺激であると考えら れるので,このことを生かして, プライミングパラダイムを 用いることにより，空間の䨌囲気を特徴づけるときに潜 在的な手掛かりとして働く要因について調べていくこと も可能であると考えられる。 


\section{一般歩道に設置された青色·白色複合 LED 照明が生体 に及ぼす影響

$\begin{aligned} \text { O平 伸二 } & \text { (福山大学人間文化学部) } \\ \text { 渡部恭三 } & \text { (大阪府都市整備部) } \\ \text { 岡田博志 } & \text { (大阪府都市整備部) } \\ \text { 西村祐一 } & \text { (大阪府都市整備部) } \\ \text { 永留君明 } & \text { (広島化成株式会社) } \\ \text { 島田紀子 } & \text { (広島化成株式会社) } \\ \text { 濱本有希 } & \text { (名古屋大学大学院珸境学研究科) }\end{aligned}$

大阪府では環境・経済・安全の3つの特性を併せ持 つ，青色・白色複合LED照明を用いた道路照明を，都 市計画道路富田目坦線に設置した。この照明は従来の 青一色とは違い，離れて見た場合は青色に見えるが， その直下は白く高い照度を有している。本実験では, 富田目垣線にある歩道用の青色・白色複合LED照明と 従来のナトリウム灯照明を実験参加者に対し5分間暴 露し, 脳波 $\left(\mathrm{Fp}_{1}, \mathrm{Fp}_{2}, \mathrm{O}_{1}, \mathrm{O}_{2}\right)$, 心拍，呼吸，瞬目を測定し た。また, 両照明の印象評定も実施し, 青色・白色複 合LED照明の心理・生理的効果について検討した。

\section{方法}

参加者 実験に同意した女子9名，男子9名，合計18 名(平均年齢22.9歳) の大学院生と大学生である。

実験装置 脳波, 心拍, 呼吸, 瞬目の測定は, 携帯 型多用途生体アンプ（TEAC社製Polymate-AP1000）を 用い，心拍は第誘導により両手首から導出した。心拍 はR-Rインターバル再生解析機能プログラム(のるぷろ ライトシステムズ)で解析し, 周波数分析はMemCalc を使用してLF，HF及びLF/HFを算出した。

手続き 実験参加者は, 電極等の装着終了後, 歩道 に置いた椅子に座り，青色・白色複合 LED 照明(青白 LED 条件)と従来のナトリウム灯照明(ナトリウム条 件)の下で，それぞれの照明を 5 分間暴露されながら， 前方歩道上の照明を注視した。実験順序は参加者間で カウンターバランスを行い, 条件前後には唾液アミラ 一ゼの採取，条件後には両照明に対寸る印象評定を行 ってもらった。なお，参加者の足下の垂直面照度は， 青白 LED 条件で約 301x，ナトリウム条件で約 701x で あった。実験は 1 月の午後 6 時から午後 9 時の間に実 施した。

\section{結果及び考察}

図 1 は両条件における $\mathrm{O} 1, \mathrm{O} 2$ の 5 分間の $\alpha$ 波含有
率である。 $\alpha$ 波含有率は, 青白 LED 条件の $\mathrm{O} 1$ で $23.0 \%$, $\mathrm{O} 2$ で $22.6 \%$ ，ナトリウム条件の O1 で $22.6 \%$, O2 で $22.5 \%$ とほとんど差はなく, 2 要因分散分析の結果も両 要因の主効果, 交互作用ともに認められなかった。ま た, $\mathrm{Fp}_{1}, \mathrm{Fp}_{2}$ の $\beta$ 波含有率も有意差は認められなかった。

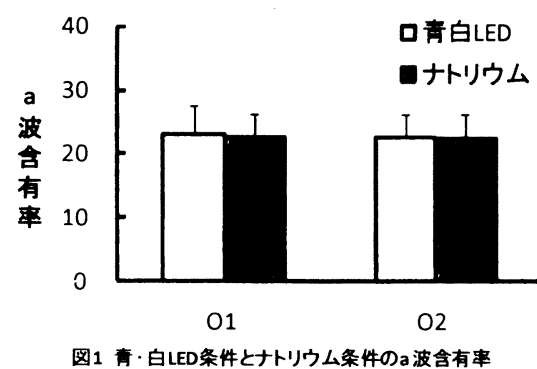

5 分間の平均心拍数(図 2 , 欠損值 1 )は, 青色・白色 複合 LED 照明で 70.2 拍，ナトリウム照明で 71.1 拍と なり，有意傾向が認められた $(F(1,16)=3.078, p<.10)$ 。 また, 副交感神経系の機能を反映する HF 值（図 3) は，青色・白色複合 LED 照明で有意に高くなった $(F(1,16)=3.078, p<.05)$ 。一方, 交感神経系活動の機能を 反映する $\mathrm{LF} / \mathrm{HF}$ 率には有意差は認められなかった。な お，呼吸数に両条件の有意差は認められていない。し たがって，5分間の平均心拍数の差異は, 青色・白色 複合 LED 照明下での副交感神経系の機能促進が原因 と示唆される。
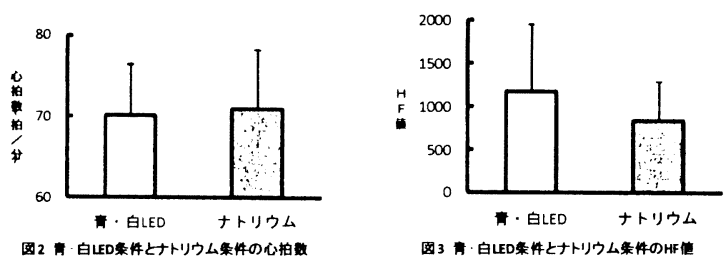

さらに，質問紙による印象評定は，「好き」「澄んだ」 「はっきりとした」「美しい」「安定」「静的」「鎮静」 「新しい「「鮮やかな」の項目で, 青色・白色複合 LED 照明の得点が有意に高く, 歩道用照明として好まれて いることがわかった。

以上のことから, 青色・白色複合 LED 照明は, 副 交感神経系の機能促進で鎮静効果をもたらすとともに, 夜間でも明確に対象が映し出され，青一色の不自然さ は軽減され，新奇性も得られることから，歩行者や周 辺住民に好まれ，生活の質(QOL)を維持したうえでの 犯罪抑止効果が期待できると考えられる。

【謝辞】本研究の実施にあたり，広島化成株式会社よ り研究助成を受けました。ここに記して感謝の意を表 します。 


\section{色が人間の免疫・内分泌系に及ぼす影響に関する統 合評価研究}

○野村収作（長岡技術科学大学産学融合トップランナー養成 センター)

\section{1. 研究の目的}

本研究では環境の色が人間におよぼす生理心理 効果について統合評価研究を行った。とりわけ、本 研究では生体内部に分泌されるホルモンや免疫物質 などの生化学物質に注目をした。

「暖色は温かく感じる」という Hue-heat 仮説に代表 されるように、色が人に様々な心理的変化を引き起 こすことは経験的にはほぼ自明であるが、そのメカ 二ズムや或いは生理心理学的な機序についての統一 的な理解は末だなされてはいない。色の生理効果に 着目すると、一般に赤色は血圧や心拍を上昇させ、 青色はその反対の効果を持つと理解されることが多 いが、相反する実験結果も少なくない。このことに 対し、色が与える生理的な効果は音や匂いなどの他 の感覚入力刺激に対して “弱く”、結果的に有意な差 異として認められないと推察されている。

本研究では、そのように検知することが難しいと考 えられる色環境に対する生理効果を、唾液中に含ま れる各種生化学物質を用いて評価し、色により生体 内部に引き起こされる身体的な変化を検証した。

\section{2. 方法}

被験者 20 名（成人男性、平均年齢 23.5 歳）に対 し、単純な精神作業（暗算計算）を 30 分間課した。 その際、色環境を疑似的にコントロールする為、赤、 青、透明の 3 種類の色メガネを装着させた。透明を コントロール条件とし、被験者内デザイン（色につ いてカウンターバランス）により実施した。精神作 業の前後に 10 分および 15 分の安静時間を設けた。 心理指標として精神作業の前後に心的ストレスに関 する質問（VAS）を、生理指標として脳波・心拍・連 続血圧・皮膚電気抵抗・皮膚温度、および唾液から 数種類のバイオマーカーを定量した。

\section{3. 結果}

統合評価した全ての各種心理・生理評価指標にお いて、色条件の違いにより明確に差異が認められた のはある種の唾液バイオマーカーのみであった（色 条件における主効果あり；p<0.1)。図 1 に結果の例
として、血圧の推移ととあるバイオマーカーの変化 を示す。図に認められるように、血圧においては、 作業期間と休蒩期間の区別は明確に認められるもの の、色条件の違いについて差異は認められなかった。 これに対し、バイオマーカーにおいては特に青色の 条件下において、コントロール条件と比べて明確に 異なる動態を示している。このことは電気生理指標 のみならず心理評価においても色条件による明確な 差異が認められなかったことを鑑みれば興味深い結 果であると考えられる。

4. 考察

唾液中のバイオマーカーにより色条件により異 なる生体内部への影響の様子が観察された。バイオ マーカーは単なる評価指標では無く、それぞれが重 要な生理機能を担う生化学物質である。したがって 色環境により生体内部に不随意的な変化が引き起こ されるのであれば、カラーセラピーなどへの応用が 期待される。無論、複雑な生理一心理現象に対する 安易な解釈やアプローチは、往々にして実質的な応 用研究に対する妨げとなる。冒頭に述べたように色 が与える心理的効果は経験的には自明であるが、生 理反応を含むその機序は理解されていない。本研究 は、そうした色が人に想起させる”感性”と、その生 体反応を紡ぐ”感性生理学”とも呼べる学際的分野の 発展の契機となりうると考えている。
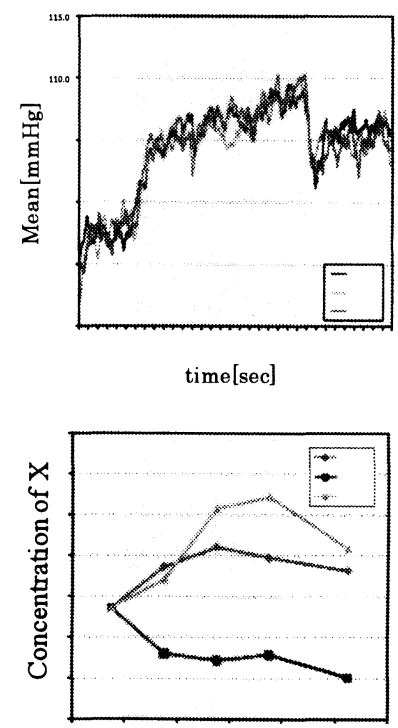

図 1.（a）連続血圧、および（b）あるバイオマーカーの 変化。中央の扊色の時間帯が精神作業 


\section{感情研究における家庭用血圧計の利用可能性}

$\bigcirc$ 手塚洋介（大阪体育大学体育学部）・山口大輔(同志社大 学心理学研究科) - 鈴木直人 (同志社大学心理学部)

\section{目的}

心臓血管系精神生理学には, 心理的要因が循環系 機能に及ぼす影響を検討する基礎的目的と，感情や ストレス体験と健康との関係性の理解を深める応用 的目的とがある(Brownley et al., 1999)。心臓血管 反応の計測には, 専用デバイス, 生体アンプ, 制御 用 PC など高度な精密機器を用いるのが一般的であ る。こうした計測環境は, しかしながら, その整備 に費用がかかり，複数の装置を使いこなすための技 能も必要とされる。一方, 最近では個人の健康管理 が重要視され, 安価で高機能な血圧計が市販されて いる。そこで本研究では，こうした家庭用の市販血 圧計が感情研究での使用に耐えうるかを検討するこ ととした。

\section{方法}

実験参加者 男女大学院生 10 名 (男性 3 名, 女性 7 名，22-32 歳)であつた。

課題 評価的観察を伴う暗算課題を採用した。モ ニタに 4 つの数字を組み合わせた四則演算の式を呈 示し, 口頭で回答させた。課題の遂行に際し, 基準 を下回らないよう教示し，モニタ表示を利用して時 間切迫感を与え, また, 実験参加者の右隣 $50 \mathrm{~cm}$ に男 性の観察者を配置して，一問毎に正否のフィードバ シクを与えた。

装置と指標 右腕上腕にオシロメトリック法によ る家庭用血圧計 (HEM-7011，才ムロンヘルスケア)の カフを装着した。左腕の上腕と手首にトノメトリ式 の連続血圧計 (JENTOW-CS, 日本コーリン)のカフお よびセンサを装着し, 右前腕と左足首に心電図(標準 第 II 誘導) を導出するため電極を装着した。れれの 波形はPCに記録された。各装置を利用して, 収縮期 血圧 (SBP), 拡張期血圧 (DBP), 心拍数 (HR) を求めた。

手続き 実験参加者は, 装置装着後に安楽椅子に 腰掛け, 順応期として雑誌講読をして 15 分間待機し た。続いて, 安静期として 3 分間安静にするよう指 示された。続いて課題説明を受けた後, 数問の練習 を経て, 2 分 40 秒間の課題を遂行して実験を終了し
た。家庭用血圧計は，安静期は 2 分 30 秒，課題期は 1 分 30 秒の時点で実験者がスイッチを押した。

データ処理 連続血圧計および心電図で計測した 波形をもとに，SBP，DBP，HR について 30 秒間毎の 平均を算出した。安静期は 2 分 30 秒, 課題期は 1 分 30 秒からの 30 秒間のデータを, 家庭用血圧計と の比較に用いた。

\section{結果および考察}

すべての指標の值が, 課題遂行に伴い増加した (図 1)。装置 $(2) \times$ 期間 (2) の分散分析の結果，いず れの指標も期間の主効果が有意であった (SBP: $F$ $(1,9)=35.50$, DBP: $F(1,9)=31.62$, HR: $F(1,9)=27.51$, $p \mathrm{~s}<.01)$ 。また, 各装置の変化值について相関係数を 求めた結果, ほぼ類似の変化を示すことが示唆され た(図 2)。

本実験の結果から，本研究のように反応をブロッ ク単位でみていく場合には, 家庭用血圧計を用いて 課題遂行に伴う反応の推移をとらえることができる と思われる。また，安価なため複数台を用いて多人 数の同時計測なども比較的容易に実施可能になるこ とから, 感情心理学研究の発展に寄与するものと期 待される。

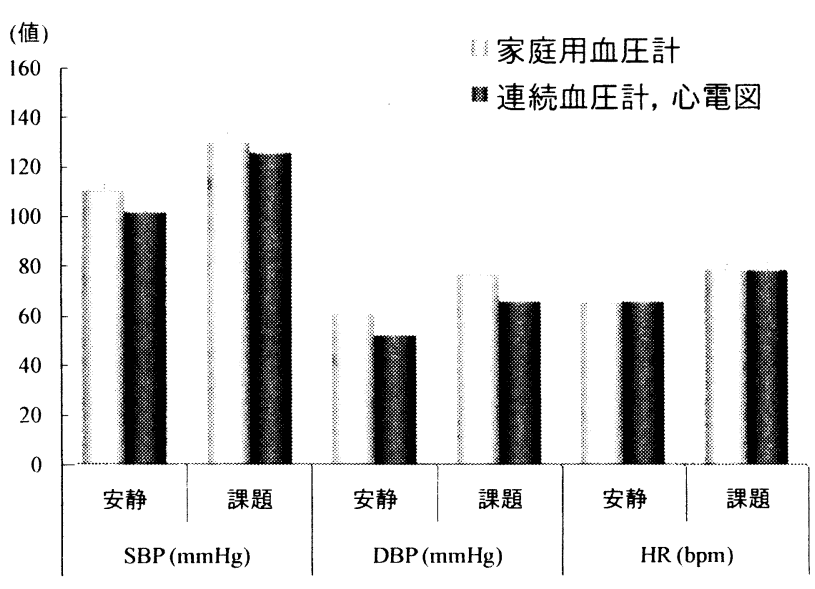

図 1. 各装置の心臓血管反応の平均と標準誤差
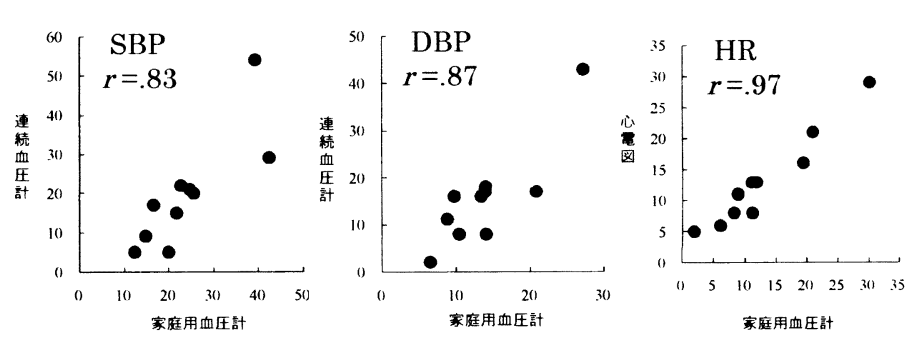

図 2 装置間の変化值の相関係数 


\section{Phase Plane Plot を用いた末梢血管反応の評価} 一安静時および課原遂行時における検討一

$\bigcirc$ 今西明 (関西学院大学文学研究科・日本学術振興会)

雄山真弓 (大阪大学大学院基礎工学研究科)

\section{序論}

末梢血管反応の中でも, 特に指尖容積脈波（以下, 脈波とする) は測定が大変簡便で, 且つ, 心的状態を 鋭敏に反映するため, 有用性の高い測度であると考 えられる。脈波を定量化することは難しく，規準化 脈波容積や加速度脈波など, 種々の解析法および加 工法を用いたアプローチが成されているが，その評 価手法が確立されているとは言えない。

そこで, 本研究では, 脈波の定量化に関する一つ の試みとして, Denton et al. (1990)によって提唱さ れた Phase Plane Plot（以下，PPP とする)を脈波 に適用し，暗算・鏡映描写課題遂行によるストレス 負荷時おける末梢血管反応の評価を行った。

\section{方法}

参加者：男性 18 名を対象とした。平均年齢は 23.3 歳（範囲：21-26 歳)であった。

手続き: 安静条件, 暗算条件, 鏡映描写条件を設け, 参加者内要因計画で実験を実施した。なお，暗算 課題および鏡映描写課題は三宅（2002）によって 作成されたものを用いた。条件の実施順はカウン ターバランスを行い，全条件共に 300s 間実施し た。各条件実施中に脈波を測定した。サンプリン グ周波数は $200 \mathrm{~Hz}$ ，時定数は $1 \mathrm{~s}$ であった。

PPP の描画：PPPは横軸に分析対象の信号の振幅值, 縦軸に信号の微分波形を 2 次元座標平面上にプロ ットする。これにより，信号の周期性や信号の変 曲点を明確に表すことができる。また，信号にお ける時間情報も保存される。なお，本研究ではデ イジタルフィルターを用いて, 脈波の基線変化成 分およびアーティファクトと考えられる高周波 成分（1Hz 以下および $10 \mathrm{~Hz}$ 以上）を除去した。

\section{結果および考察}

18 名の参加者のうち, 顕著な変化を示した 1 名を 対象にPPP を描画した。なお, PPP の描画は 5 分 間の測定のうち, 最後の 2 分間のみを対象としてい る。Fig. 1 は各条件における PPP を示している。黒 色のプロットは前半, 灰色は後半を表している。Fig.
1 より, 鏡映描写条件が他の条件と比較して, 最も 微分振幅值が低く, さらに前半よりも後半において 減少している。また, 安静条件は軌道が周期的であ るが, 両課題条件の軌道は摇らぎが生じていること がわかる。ストレス負荷により, 微分振幅值が低下 していることは交感神経系の賦活を示し，血管壁の 緊張が高まっていると考えられる。以上のことから， PPP を用いて, ストレス負荷による末梢血管反応の 評価を行える可能性が示唆された。
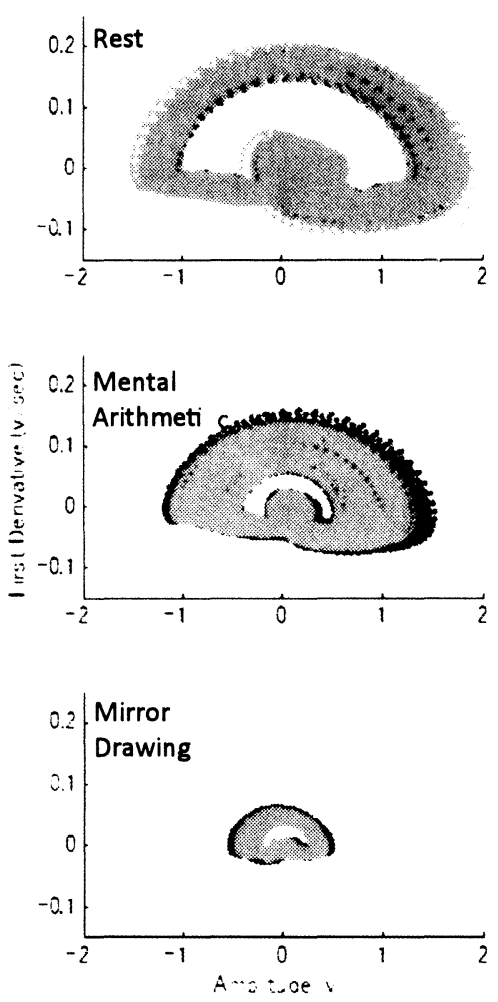

Fig. 1. Phase plane plot (PPP) in a representative subject

\section{文献}

Denton, T. A. et al. (1990). Fascinating rhythm: A primer on chaos theory and its application to cardiology. American Heart Journal, 120, 1419-1440.

三宅晋司 (2002)。実験室実験用主観指標と精神課 題プログラム S.I.M.P.L.E.について. 人間工学, 特別号 38,332-333.

本研究の実施にあたり, 高橋龍尚先生（旭川医科大学） に多大なるご協力を賜りました。心より感謝致します。 


\section{摂食に伴う内臓感覚表現尺度の妥当性の検討}

○中島佳緒里（日本赤十字豊田看護大学）

櫻井優太 (愛知淑徳大学心理学研究科)

清水遵 (愛知淑徳大学コミュニケーション学部)

\section{1. 目的}

本研究では, 我々が作成した満腹感に関する内臓感覚 表現尺度の妥当性の確認を目的として, 摂取カロリ一量 に随伴した尺度得点の変動と自律神経指標の関連，およ び尺度得点の時間経過に伴う変動を検討した。

\section{2. 摂取カロリ一随伴実験}

\section{2-1. 測定内容・方法}

【実験参加者】胃腸疾患や自律神経系疾患，不整脈を指 摘されたことがない健常な成人 11 名, 平均年齢 22.7 歳 $(S D=4.0)$ であった。【測定項目】(1満腹感の程度 : 両 極に ‘全くない’ ‘非常にある’を記した $10 \mathrm{~cm}$ の VAS を用いた。(2)内藏感覚表現尺度 : 作成した尺度を使用し た。この尺度は「容量・重量因子」 12 項目，「運動因子」 5 項目で構成されていおり，4段階評定尺度を用いて評 価した.【自律神経活動】自律神経活動の測定分析には, PowerLab(AD insturuments 社)を用いた。心電図は BioAmp を, 血圧は容積補償型連続血圧計 (Finapres 社）を通してサンプリング周波数 $1 \mathrm{kHz}$ で記録された。 【試験食】とろけるプリン』(永谷園) $100 \mathrm{ml}$ (175kcal) を用いた。【手続き】参加者には, 椅子座位にて 5 分間 安静後, (1)と(2)の記入を求めた。その後“飲んで下さい” の合図に従って, 試験食を摂取した。摂取直後および 15 分後に(1)と(2)の記入が求め実験を終了した。心電図と連 続血圧計は実験開始から終了まで連続的に測定された。

\section{2-2. 分析方法}

VAS および内藏感覚表現尺度に関しては, それぞれの 得点の平均值を算出し, 測定区間毎 (摂取前, 搷取直後,

15 分経過後）に比較した。また, 心電図より得られた LF/HF を交感神経活動, 連続血圧より得られた圧反射感 度（BRS）を副交感神経活動指標とした。

\section{2-3. 結果}

【VAS・尺度得点の推移】満腹感を示寸平均 VAS 值は, 摂取直後より上昇し, 15 分後まで維持した。内臓感覚表 現尺度のうち「容量・重量因子」は, VAS 值と同様の推 移を示した。分散分析の結果, 満腹感および「容量・重 量因子」は有意差を認め（それぞれ $F(2,20 ）=21.0, F$ $(2,20)=17.7, \quad p<.01)$, 掑取前に比べ拱取直後および 15 分経過後は有意に高值を示した。「運動因子」は摂取 前にやや高い傾向を示したが，有意ではなかった。自律 神経活動】 LF/HF は, 撕取直後に上昇した。分散分析の 結果は有意であり $(F(2,20)=7.7, p<.05)$, 摂取前よ りも摄取直後に有意な上昇を認めた。圧反射感度は, 摂 取 15 分経過後にやや上昇傾向があった。

\section{3. 尺度得点の時間経過に伴う変動実験}

\section{3-1. 測定内容・方法}

【実験参加者】健常な成人 13 名, 平均年齢 28.0 歳
$(S D=2.2)$ であった。そのうち 9 名が 2 回目の実験に参 加した.【測定項目】前述した(1)と(2)を用いた。【試験食】 総摂取カロリー $600 \mathrm{kcal}$ の市販の弁当と $350 \mathrm{ml}$ の緑茶を 用いた。【手続き】参加者には，試験食の摂取前・直後・ 30 分後・60 分後, 以降 360 分まで計 9 回, (1) と(2)の記入 を求めた。実験中の飲食および連動は禁止とし，指定の 場所で自由に過ごすよう指示した。2 回目の測定は，捸 取前・直後・ 30 分・ 120 分・180 分後の計 5 回とした。

\section{3-2. 分析方法}

満腹感と内臓感覚表現尺度尺度の平均値を算出し, 経 過時間毎の比較をした．また，「容量・重量因子」は各参 加者の得点をプロットし, RI 胃排出試験の T1/2 值との 比較をし，パターン化した．さらに，1回目と 2 回目の 測定值から再現性を確認した。

\section{3-3. 結果}

【時間毎の推移】満腹感は摂取直後に急上昇し, その後 徐々に低下した。分散分析では有意差を認め $(F(8,96)$ $=105.9, p<.01)$, 多重比較の結果, 摂取前に対し攝取直 後から 300 分後までの上昇は有意であった。「容量・重量 因子」得点は満腹感と同様に推移したが，満腹感に比心゙ 摂取 120 分後までは分散が大きく, 逆に 240 分以降は小 さかった。分散分析では有意差を認め $(F(8,96)=39.9$, $p<.01)$, 多重比較の結果, 摂取前に対し摂取直後から 180 分まで有意に高値を示した。一方，「運動因子」得点は， 摂取前と 300 分以降に高くなる傾向を示したが，有意差 は認められなかった。【容量・重量因子」のパターン】

「容量・重量因子」得点の推移は, RI 胃排泄試験におい てT1/2 となる摂取後 120 から 180 分区間で得点が大きく 減少するパターンを示した 7 名, それよりも遅延した 1 名, 促進した 1 名, 低い得点で推移した 2 名の 4 パター ンに分類された。【容量・重量因子」の再現性】1回目 と 2 回目の測定值のパターンは類似しており, 尺度得点 の再現性が確認された。

\section{4. 考察}

我々が作成した内臟感覚表現尺度の「容量・重量因子」 項目は，カロリーのある食物摂取により得点が上昇し, 摂取後 15 分まで維持された。この変動は, 先行研究に おける満腹感の変動と一致しており, カロリ一摂取によ る胃から十二指腸への排出遅延と甘味による知覚の充進 が生じたためと考える. また, 「容量・重量因子」得点は, 180 分以降に摂取前との有意差がなくなったこと, RI 胃 排出試験と同じパターンの参加者が多かったことから， 満腹感よりも敏感に胃容量を反映するだろう。さらに, パターン毎の再現性が確認でき, 内臓感覚を捉える上で

「容量・重量因子」項目は妥当である。一方，BRS の結 果からカロリ一㠌取後の迷走神経活動は方進する傾向を 示したが，「運動因子」項目との関連は明確にならなかっ た。摂取後は「容量・重量因子」の知覚が大きいために,

「運動因子」の知覚が遮蔽されている可能性が考えられ る。今後, 味覚統制条件等を加え,「運動因子」と消化管 活動の関係を明確にする必要がある。 


\section{アシスティブデバィスのバィタルセン サによる機能計測}

内久根聖志 (日本大学 理工学部)

\section{1 . 目的}

長時間のシーティングは, 姿勢状態も含めて生 体に対しては影響を与えるものと言われている。 長時間の椅座位による原因で裖瘡に変化する例も 挙げられている。これは,アシスティブデバイス である wheelchair や用具の使用した条件にも同様 の事が言えることから, 日常生活の質的向上 （QOL）のためとして，普及されている wheelchair と機能の恒常性維持するための用具を 用いて, シーティングのバリアント特性と身体機 能に合わせるティルトと座面角度の効果について, 生体一の影響を検討した。生理計測による生理指 標としては, 心臓血管系の反応に, 心拍数, 指尖 容積脈波, 血流, 未梢皮膚温, 呼吸器系の反応と しては, 呼吸数, 唾液分泌機能としては, 唾液分 泌量, 表面筋に関連した指標には, 筋電位反応, 他には, 生体信号, 平衡機能等について計測した。 感性計測については, VAS と SD 法からバリアン トタイム特性による評価項目の相関を検討した。

\section{2. 方法}

スリングシート上に用具使用のシーティング姿 勢状態（60 分）についてのティルト $\left(2.2^{\circ}\right)$, 座面角度 $\left(11.7^{\circ}\right)$ の機能の生理計測法には, 条 件として, 自律神経系の反射を介する機能を検出 するための方法を取りあげた。

いずれも，生体に最適に成形した座位保持用具 を使用した条件による計測を行い，その時系列の 3 分毎に計測した值の最初の 3 分をべースライン 值に取り, 各経過時間毎の值との比率で示した。 自律神経系活動の低下寸る時系列を検出し, さら に約 $30 \%$ 濃度のエア, 同時閾の大となる広背部加 温負荷時 (平均 $314.4 \mathrm{~K}$ で 20 分) と大腿部加温負荷 時 (平均 $317.3 \mathrm{~K}$ で 20 分)による場合について検討 した。座位前・後の場合を比較するために平衡機 能計, 加速度計, 頭頂部の中央に加速度センサを 取り付けて測定した。平均身長: $169.3 \mathrm{~cm}$ - 体 重: 611.4Nの男子大学生 8 名の被験者に対して,
平均室温: $296 \mathrm{~K}$, 平均湿度: $57 \%$ の条件で行った。 3 . 結果

生理指標評価結果としては, 以下に提示する。 心拍波高值比は, エア供給, 加温負荷時による効 果で特異性反応傾向を示した。同様による効果で, 心拍周期の増加は定位反応を反映していることが 見出された。呼吸数比は, エア供給時の 33 分と 48 分後による供給効果を反映することが示され た。この傾向は 54 分後による加温効果も反映す ることが示された。唾液分泌量は, 温熱性刺激で 起こる無条件反射分泌を反映する効果により, 促 進傾向を示した。足部位の血流は, Dorsum, Tibalbone ともに 33 分〜 48 分後は, エア 供給, 加温による効果により, 血流量の值が高く 示された。生体信号の出現する割合の算出結果は, $\alpha / \beta$ 比として見た場合は, エア供給, 加温負荷 による効果で増加する傾向が生起した（33 分〜 36 分）。コントロールの 27 分〜 60 分では, $\beta$ 波 の中心周波数 $24 \mathrm{~Hz}$ が増加傾向で生起した。同時 計測の中心周波数 $10 \mathrm{~Hz}$ の $\alpha$ 波が減衰傾向を示し た。加温負荷後には $\alpha$ 波が反応を示したことは, 蓄温効果として考えられる。皮膚温度比は, コン トロールの 33 分〜 60 分間で減少傾向を示した middle finger, big-toe, arch 部位においては, 加 温負荷時では, 逆の効果を示した。筋電位反応で は, 左右僧帽筋と右広背筋上部・下部ともに, シ 一ティング開始後 6 分の負荷前に比べて広背部, 大腿部加温時で約 3.5 4.5 倍の筋活動電位比が 現れ，筋活動量を生起させたためと考えられる

(平均筋電図量変化)。また, 筋電図からの平均 周波数帯域比は, 負荷時では増加傾向を示した （筋の質反応変化）。

SD 法から算出したエア供給姿勢の一心地よい -・一疲れていない一の時間（30-50-60 分）と のタイムバリアント相関係数は， $0.57,0.93$ 值 の感性評定值を示した。

\section{4. 考察}

シーティングの使用条件に対するバリアントタ イム特性による機能計測により, 生理指標の変化 する傾向が示唆されたことは, 自律神経系各指標 の拮抗作用の量的度を持続性の変化する水準を 維持, 反映させることの必要性がある。 


\section{肩の筋硬度計測の生理心理学的研究}

○内田誠也 - 津田康民 - 木村友昭 - 山岡淳 - 菅野久 信（財団法人厸·オ-・エー健康科学センター）

1.はじめに

国民統計データを用いて心理社会的ストレスと 筋骨格系症状の関連を調べた研究では、肩こりと自 覚ストレスには相関が見られたと報告されている。 この研究では肩こりを評価する方法として質問紙の みであり、生理的な指標との関連は研究されていな い。肩こりは、筋肉の疲労により生じると考えられ ていることから、筋肉の硬度と関連があると思われ る。近年、簡易に筋肉の硬度計測する方法として、 圧入式硬度計が開発され、銊尒やスポーツ医学の効 果評価法として用いられている。それらの研究では、 主に 2 種類の簡易型の筋硬度計（TDM-NA1、PEK-1） が用いられており、相互の比較はなされていない。

そこで、本研究では、2 種類の簡易型の筋硬度計 が、短期的なリラクゼーション法に対して、有効化 か否かを評価することを目的とする。

本研究では、短期的なリラクゼーション法として、 岡田式浄化療法（OPT）（代替医療の一種）を用い、 コントロール (ベッドの上で横なるのみ) と比較し た。計測は、首および肩の筋硬度の他に、首や肩の 自覚的痛みおよび硬さ、心拍変動、唾液アミラーゼ、 POMSを計測した。

\section{2. 実験方法 および対象}

被験者は、OPT をベッドの上で 1 時間施術される リラクゼーション実験とベッドの上で 1 時間横にな るだけのコントロール実験を体験した。2つの実験 は別の日に行われたが、実験開始時刻は同じであつ た。 $\mathrm{R}-\mathrm{R}$ 間隔ゆらぎ（HF 值、 $\mathrm{LF} / \mathrm{HF}$ 值）、首肩の筋硬 度、唾液アミラーゼ、自覚的痛みと硬さ、POMS が同 時に計測された。特に筋硬度計測では、PEK-1（井本 製作所)、TDM-NA1（トライオール）の 2 種類の機器 を用い、首肩部の 6 箇所を計測した。各々場所を事 前にマーキングし、3 回計測して、平均值を採用し た。対象は 30 名（男性 14 名、女性 16 名）であり、 平均年齢 35.3 (SD10.5) 歳であった。

3. 結果

筋硬度計測に関して、TDM-NA1 を用いた場合、左 右肩および右肩の付け根においてリラクゼーション 実験の硬度の方が有意に低下した（図 1 )。一方、
PEK-1 を用いた場合、すべての測定箇所で有意な変 化は見られなかった。自覚的痛みは右首の付け根以 外の箇所で、リラクゼーション実験の方が有意に低 下した。自覚的硬さはす心゙ての測定箇所で、リラク ゼーション実験の方が有意にやわらかくなった。HF 值に関しては、リラクゼーション実験中に、有意な 増加が認められた。LF/HF 值に関しては、コントロ 一ル実験で、有意な増加が見られた。POMS の活気に 関して、リラクゼーション実験の方が、有意に上昇 し、混乱に関しては有意に低下した。唾液アミラー ゼに関しては、両実験ともに低下したが、有意な違 いはみられなかった。

\section{4. 考察およびまとめ}

OPT を用いたリラクゼーション実験では、HF 值が 増加し、LF/HF が維持され、リラクゼーション効果 が確認された。肩の筋硬度は、TDM-NA1 で計測した 方がリラクゼーションによって有意に低下した。肩 の筋硬度計測は短期的なリラクゼーション効果を評 価することができたと考える。また、HF 值の変化と 比較して、肩の筋硬度計測の変化の方が、有意差が 大きかったことから、簡易的な評価方法として有益 であることが考えられる。

測定限界として、限られた部位しか測定しておら ず、首肩全体でどの部位がリラクゼーションにもつ とも感度が高い部位か検討すべきである。また、測 定場所は、骨の位置によって決定しているが、測定 者によって測定位置のずれが生じる可能性があるた め、個人差がでにくい位置決めを検討す心゙きである。 2 種類の筋硬度しか評価しておらず、さらに測定条 件が違う計測方法も比較する必要があると考える。

結論として、肩の筋硬度計測は、リラクゼーショ ン効果を評価する方法として有効である。
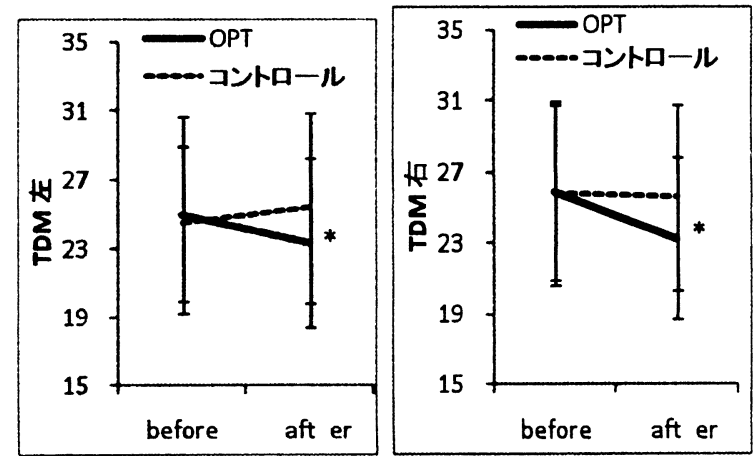

Figure 1 左右肩の筋硬度計測の結果. $*: \mathrm{p}<0.05$ 